\title{
Size Distributions of Aerosol Particles in the Free Troposphere: Aircraft Measurements in the Spring of 1991-1994 Over Japan
}

\author{
YASUNOBU IWASAKA ${ }^{1}$, IKUKO MORI ${ }^{1}$, MASAHIRO NAGATANI ${ }^{1}$, HIROSHI NAKADA ${ }^{1}$, \\ KATSUJI MATSUNAGA ${ }^{1}$ and HIDEAKI NAKANE 2
}

(Manuscript received 19 August 1994, in final form 25 August 1995)

\begin{abstract}
Measurements of number-, mass-, and volume-size distributions of free tropospheric aerosols were made over Japan in the spring of 1991-1994.

Number-size distribution frequently shows a peak in the area of a diameter of $D \geq 1 \mu \mathrm{m}$ in the free troposphere during observational periods. A few peaks are identified in the volume-size distribution as estimated on the basis of number-size distribution having single mode in a coarse range. Mass-size distribution frequently indicate enhancement in the coarse size range. This feature of the distribution is more frequent in those measurements made at $4.4( \pm 0.3) \mathrm{km}$ than those at $2.3( \pm 0.3) \mathrm{km}$.

On the basis of a backward trajectory analysis of an air mass containing those particles, soil particles originating in the Asian continent affect the features found in the size distributions as well as vertical change in those size distributions.
\end{abstract}

(Key words: Asian dust particle, Size distribution, Free troposphere)

\section{INTRODUCTION}

Airborne measurements on the size distribution patterns of free tropospheric aerosols were made in the spring of 1991-1994 so as to give a better understanding of the behavior of particulate matter over Japan. Westerly prevailing winds seem to characterize the nature of the atmospheric particles over eastern Asia and the western Pacific region since those winds frequently carry particulate matter originating on the continent over the ocean and such particles are sometimes expected to be major in those regions (e.g.. Duce el. al., 1983; Meinert and Winchester, 1977).

Every spring, Asian dust particles are frequently transported to Japan by westerly prevailing winds. In particular, the atmospheric effect of heavy dust storms observed near the ground in Japan are familiarly called 'Kosa' in Japanese which literally means 'yellow sand'.

\footnotetext{
1 Solar Terrestrial Environment Laboratory, Nagoya University, Chikusa-ku, Nagoya 464, Japan

2 National Institute for Environment Studies, Onogawa, Tsukuba 305, Japan
} 
Many investigations on Kosa particles and their effect on radiative transfer processes and the geochemical budget of soil have been made. Those include observations of particle shape and the chemical composition with an electron microscope (e.g., Okada et al., 1990), chemical analyses of particulate matter (e.g., Gao et al., 1992; Betzer et al., 1988), assessment of the radiative effect of particulate matter (e.g., Asano and Shiobara, 1989), estimation of the load of Kosa with a lidar and radiometer (Iwasaka et al., 1988; Arao and Ishizaka, 1986) and observations on particle size distributions with a particle counter or sun-photometer ( e.g., Hayasaka et al., 1992; Tanaka et al., 1990). These investigators suggest that the particles play an important role in radiative transfer, global budget and/or the geochemical cycle of various chemical constituents in the region of east Asia and the western Pacific Ocean.

However, investigations of the behavior of Asian dust particles were made mostly on the basis of particle collection near the ground. Accordingly, measurements of particles in the free troposphere are extremely limited due to the difficulty involved in the measurement of free tropospheric Kosa particles.

The main purpose of this paper is to provide particle size distribution patterns measured in the free troposphere over Japan and to discuss the effect of soil particles originating on the Asian continent on the size distributions of the free tropospheric particles.

\section{MEASUREMENT OF NUMBER-SIZE DISTRIBUTION OF AEROSOLS IN THE FREE ATMOSPHERE}

Number- and mass-size distributions of atmospheric aerosols were measured in the free atmosphere in the spring of 1991, 1992, 1993 and 1994 over the Nagoya and Wakasa-Bay area with a particle counter and an impactor mounted on the aircraft, Cessuna 402B. The distance between Nagoya airport and Wakasa Bay is about $130 \mathrm{~km}$. Additional measurements were made over the Goto Islands area in the southern part of Japan in the spring of 1993. Sampled air was introduced into a cabin of the aircraft through an isokinetic decelerator and then distributed to the optical particle counter, the QCM cascade impactor and other equipments. The instruments used here are listed in Table 1.

Table 1. Instruments used for Aircraft Measurements.

\begin{tabular}{|c|c|c|}
\hline Instrument & Specification & Note \\
\hline Optical Particle Counter & $\begin{array}{l}\text { Model PM-730 (DAN Sangyo Co.) } \\
\text { Light Source: Halogen Lamp } \\
\text { Particle sizing: } \\
\quad 0.3->10.0 \mu \mathrm{m}\end{array}$ & $\begin{array}{l}\text { Caliburation } \\
\text { was made on } \\
\text { the basis of the } \\
\text { Japan Industrial } \\
\text { Standard (JIS) }\end{array}$ \\
\hline QCM Cascade Impactor & $\begin{array}{c}\text { Model PC-2 (Tokyo Direkku Co.) } \\
\text { Dual quartz crystal method } \\
\text { Crystal size of } 1.27 \mathrm{~cm} \\
\text { (diameter) }\end{array}$ & $\begin{array}{l}\text { Caliburation } \\
\text { was made on } \\
\text { the basis of } \\
\text { the JIS }\end{array}$ \\
\hline Lidar & see Table 3 & \\
\hline
\end{tabular}

The flight paths of the aircraft used for the measurements are shown in Figure 1, and particle collection was made during the flights at $2.3( \pm 0.3) \mathrm{km}$ and $4.4( \pm 0.3) \mathrm{km}$ altitude. Observational dates are summarized in Table 2. A thin hazy layer was frequently identified in the free atmosphere by the crew's own eyes during the observational flights. 


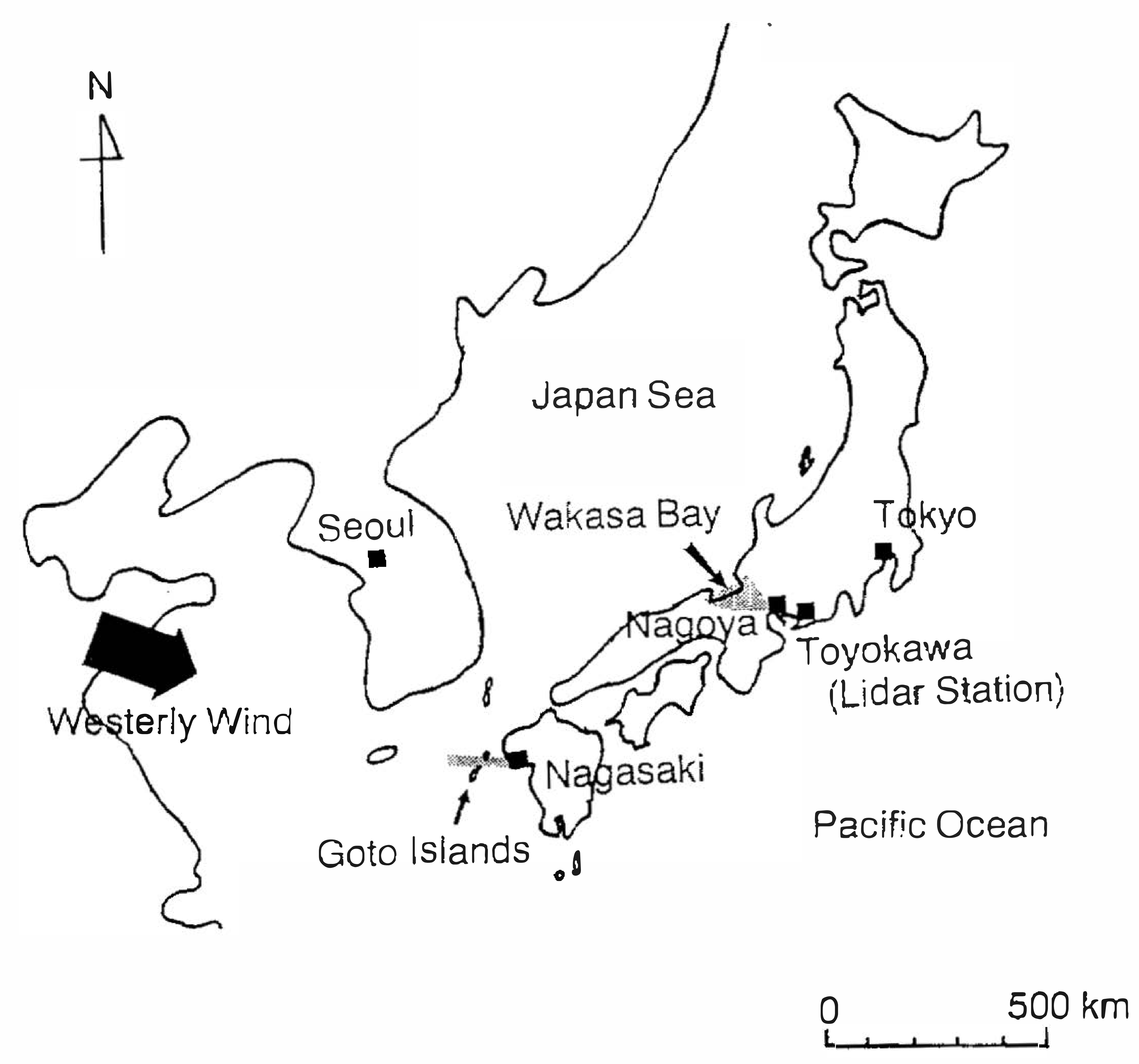

Fig. 1. Flight path used for measurements. All measurements were made over the Nagoya-Wakasa Bay area, except for one over Goto Islands area on March 8, 1993.

Table 2. Date and Altitude of Aircraft Measurements.

\begin{tabular}{lcll}
\multicolumn{2}{c}{ Date } & \multicolumn{1}{c}{ Flight Altitude $(\mathrm{km})$} & \multicolumn{1}{c}{ Area } \\
\hline April & 27,1991 & $2.3( \pm 0.30)$ and $4.4( \pm 0.30)$ & Nagoya-Wakasa Bay \\
May & 10,1991 & $2.3( \pm 0.30)$ and $4.4( \pm 0.30)$ & Nagoya-Wakasa Bay \\
January & 08,1992 & $2.3( \pm 0.30)$ and $4.4( \pm 0.30)$ & Nagoya-Wakasa Bay \\
April & 26,1992 & $2.3( \pm 0.30)$ and $4.4( \pm 0.30)$ & Nagoya-Wakasa Bay \\
December & 04,1992 & $2.3( \pm 0.30)$ and $4.4( \pm 0.30)$ & Nagoya-Wakasa Bay \\
March & 06,1993 & $2.3( \pm 0.30)$ and $4.4( \pm 0.30)$ & Nagoya-Wakasa Bay \\
March & 08,1993 & $2.3( \pm 0.30)$ and $4.4( \pm 0.30)$ & Goto Islands Area \\
March & 09,1993 & $4.4( \pm 0.30)$ & Nagoya-Wakasa Bay \\
May & 12,1993 & $2.3( \pm 0.30)$ and $4.4( \pm 0.30)$ & Nagoya-Wakasa Bay \\
February & 06,1994 & $2.3( \pm 0.30)$ and $4.4( \pm 0.30)$ & Nagoya-Wakasa Bay \\
April & 26,1994 & $2.3( \pm 0.30)$ and $4.4( \pm 0.30)$ & Nagoya-Wakasa Bay \\
\hline
\end{tabular}

An optical particle counter (DAN Sangyo Co., Model PM-730) with a halogen lamp and a phototube detector of light scattered by particles was mounted on the aircraft to measure the number-size distribution covering fine to coarse particle size. A sizing of the particles was made at $0.34 \mu \mathrm{m}, 0.44 \mu \mathrm{m}, 0.54 \mu \mathrm{m}, 0.69 \mu \mathrm{m}, 0.89 \mu \mathrm{m}, 1.1 \mu \mathrm{m}, 1.3 \mu \mathrm{m}, 1.7 \mu \mathrm{m}, 2.4$ $\mu \mathrm{m}, 3.4 \mu \mathrm{m}, 4.4 \mu \mathrm{m}, 5.4 \mu \mathrm{m}, 6.9 \mu \mathrm{m}, 8.9 \mu \mathrm{m}$ and larger than $10.0 \mu \mathrm{m}$ (diameter). The 
caliburation of the counter was done according to Japanese Industrial Standard (JIS-Z-8813) instructions as decided by the Japan Ministry of International Trade and Industry.

\section{PEAK IN NUMBER-SIZE DISTRIBUTIONS AT SIZE OF ABOUT $1 \mu \mathrm{m}$}

In Figures 2a-h, the number-size distributions of aerosols measured during the spring seasons of 1991, 1992, 1993, and 1994 are shown.

Most of the curves in Figures 2a-h show small peaks in the range of coarse particle size (mostly $0.89,1.0$, or $1.3 \mu \mathrm{m}$ diameter) at the altitude of both $2.3( \pm 0.3)$ and $4.4( \pm 0.3) \mathrm{km}$.

The density peak of coarse size particles in the surface atmosphere is considered to be due to soil and/or sea salt particles which are directly injected into the atmosphere from the local ground sources (e.g., Gillette and Hanson, 1989; Paterson et al., 1976; Twomey, 1976).

The peaks at coarse size range in Figure 2, however, are not only due to local sources but also to other sources since the height of the boundary layer top was at most about 2 $\mathrm{km}$ in the spring over Japan (Takeuchi and Kondoh, 1993). Strong westerlies prevail in the middle troposphere over Japan throughout the year except summer (Kawahara, 1992, 1993; Takano, 1994). The wind-blown dust injected into the atmosphere over the desert area of the Asian continent is, thus, considered to be a significant source of coarse particles above the planetary boundary layer.

Iwasaka et al. (1988) suggested that weak Kosa events were frequently identified in the free troposphere, typically in the altitude range of $2 \mathrm{~km}$ to $6 \mathrm{~km}$, over Japan in the spring from lidar measurements, even when Kosa events were not detected near the ground.

From the lidar measurements made at Nagoya (the Main characteristics of the lidar are summarized in Table 3), the scattering coefficient of atmospheric aerosols can be obtained. This is defined as:

$$
\mathrm{SR}=[\beta p(z)+\beta m(z)] / \beta m(z)=1+\beta p(z) / \beta m(z),
$$

where $\beta p$ and $\beta m$ are backscattering coefficients of atmospheric particulate matter and air molecules, respectively, measured at altitude $=z$ by a lidar. The value of [SR - 1] can be recognized as the mixing ratio of atmospheric particles estimated from the light scattering effect of particulate matter. The depolarization ratio is defined as:

$$
\mathrm{DR}=[\beta p(z)+\beta m(z)]-L /[\beta p(z)+\beta m] / /
$$

where the // and $\perp$ mean parallel and perpendicular component of a lidar return, respectively, showing the nonspherisity of particulate matter. The value of DR becomes only component of air molecule, $[\beta m(z)] \perp /[\beta m] / /$ which is in the range of 0.02-0.04, when the particle scattering laser beam has a sherical shape (Iwasaka, 1986). Lidar measurement made to collaborate the airborne particle-counter measurements showed an example suggesting the effect of boundary mixing on vertical profiles of aerosol content (Figure 3).

The lidar measurements in Figure 3 indicate the minimum aerosol mixing ratio at 1.8 $\mathrm{km}$ which is expected to correspond to the top of the boundary mixing layer.

Therefore, it is reasonable to suggest that the enhancement of particle number concentration in the coarse particle size range above the boundary layer is partially due to the weak Kosa events as described by Iwasaka et al. (1988). 


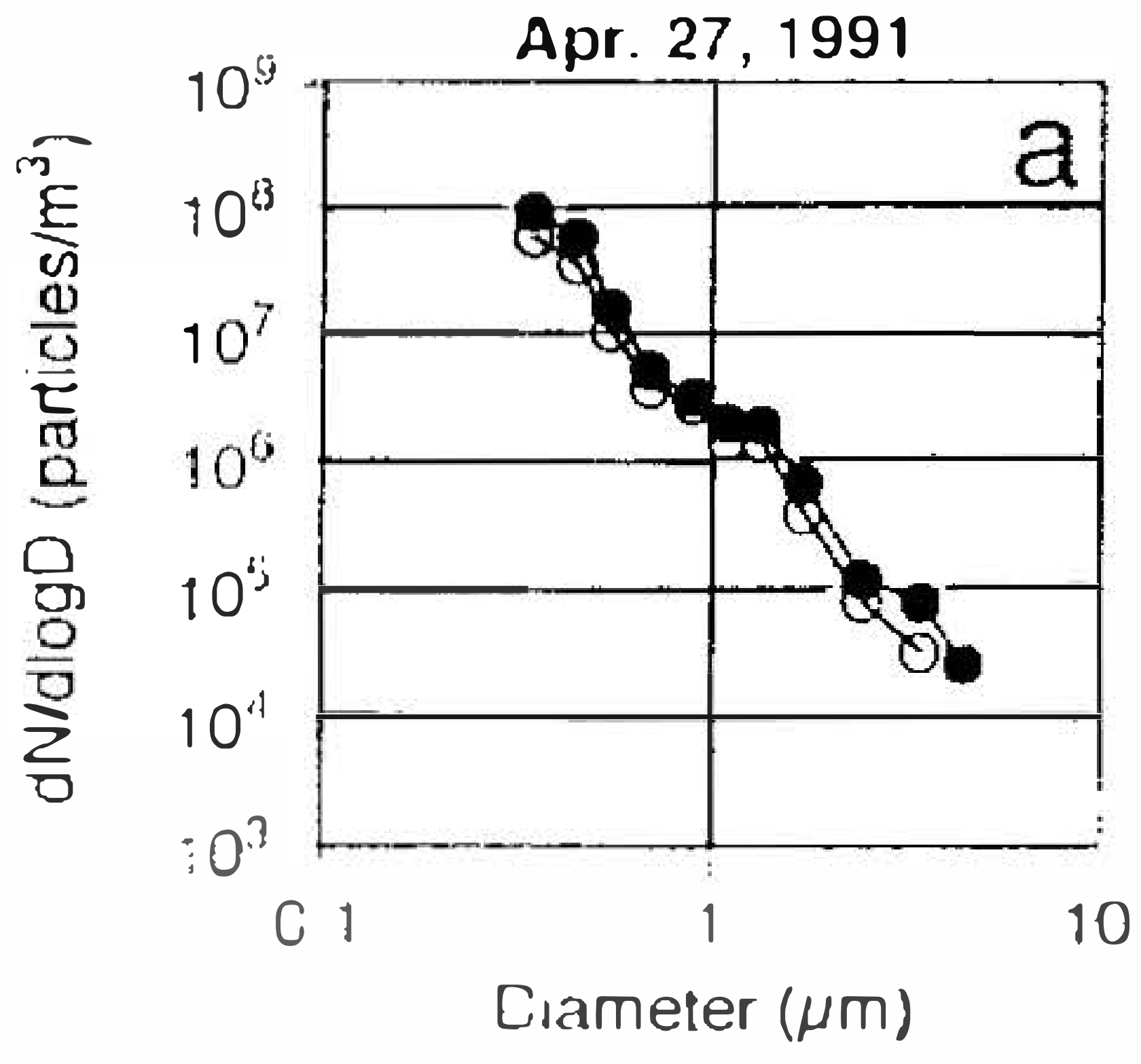

Folat Number $20 \times 10^{7} \mathrm{~m}^{3}(2300 \mathrm{~m})$ lotal Number $12 \times 10^{7} \mathrm{~m}^{3}(44 \mathrm{CO} \mathrm{m})$

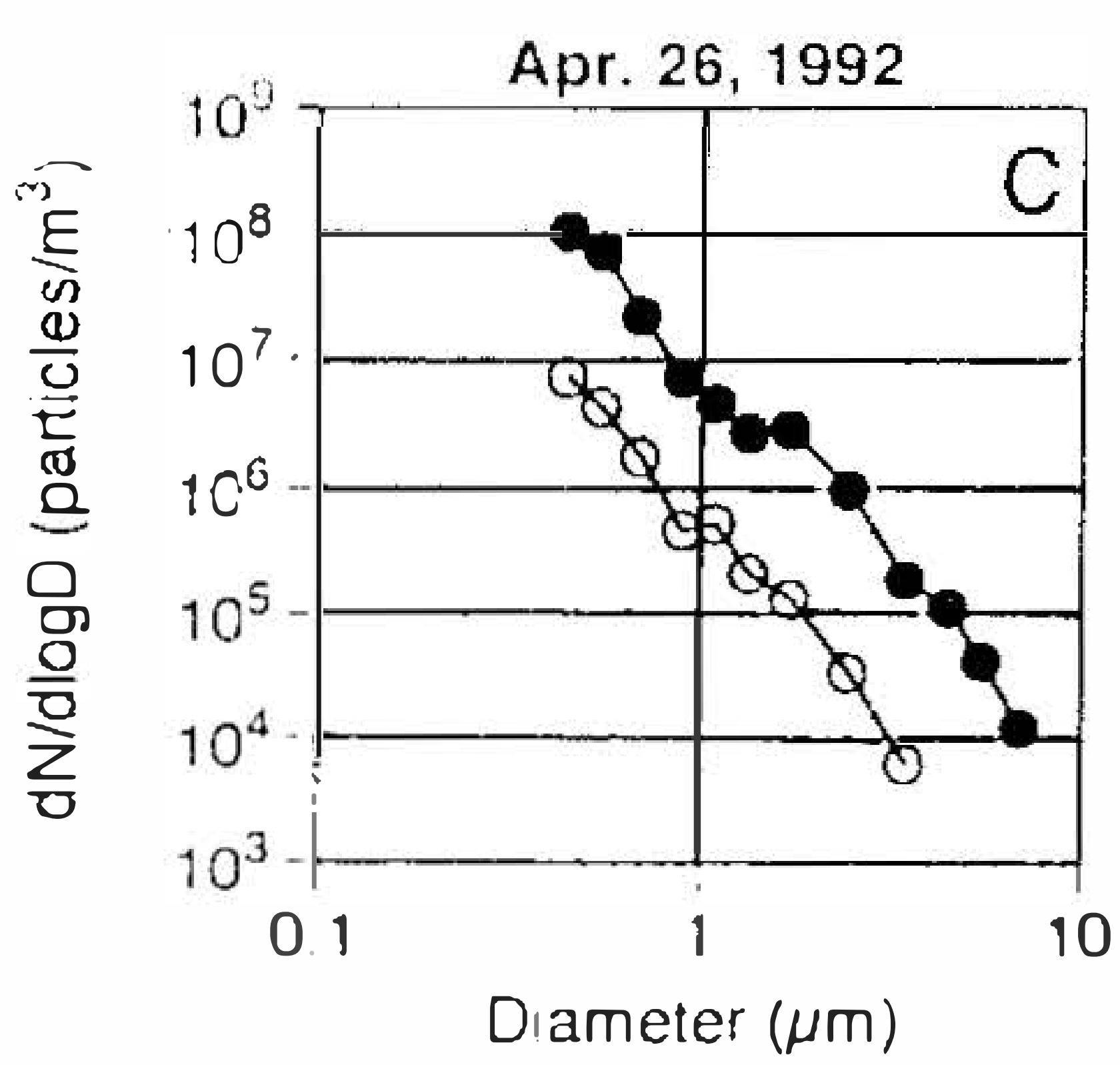

Tolal Number $2.4 \times 10^{7} / \mathrm{m}^{3}(2300 \mathrm{~m})$ Tolal Number $1.6 \times 10^{6} / \mathrm{m}^{3}\{4400 \mathrm{~m}$ )

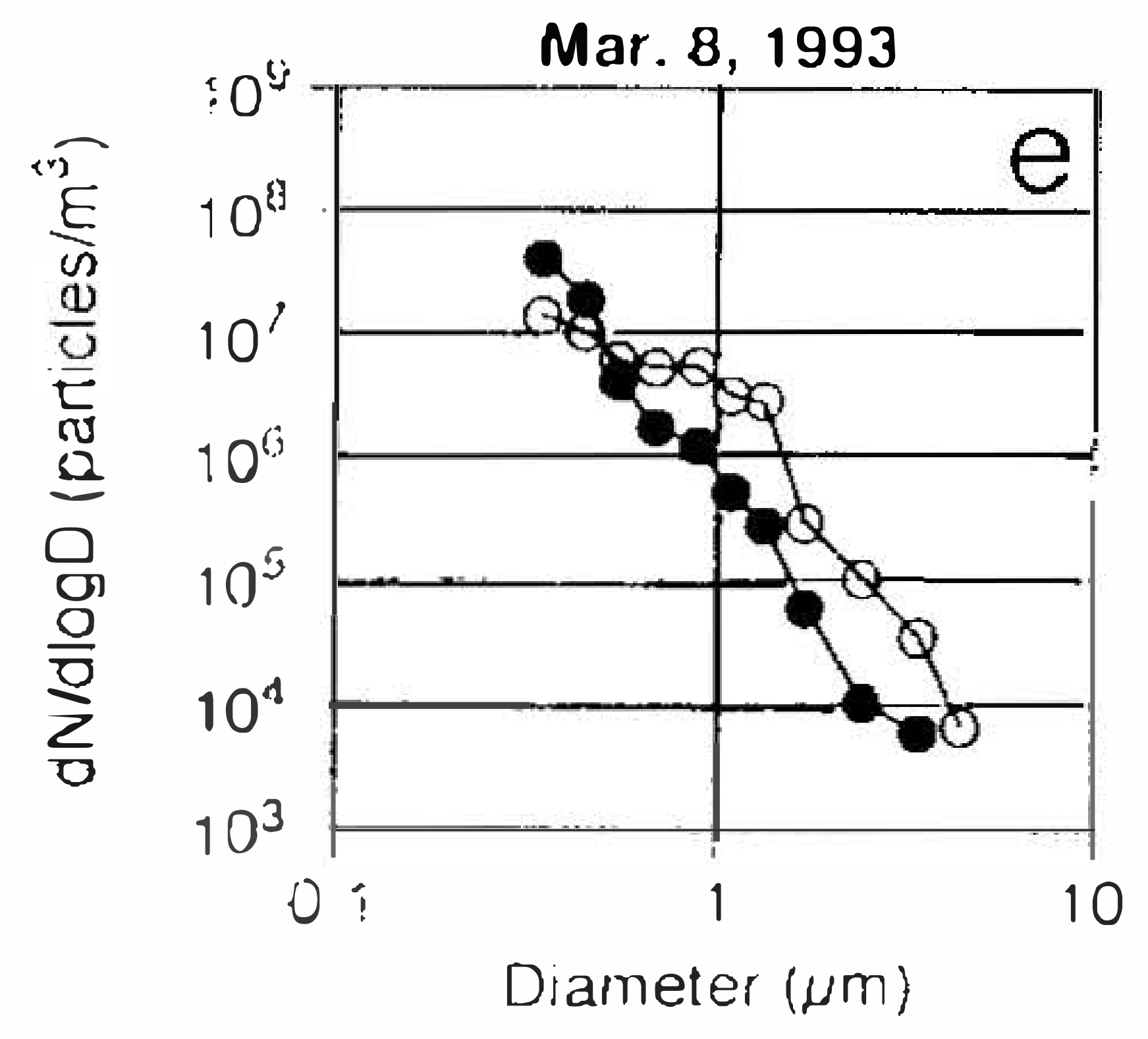

Total Number $7.6 \times 10^{6} / \mathrm{m}^{3}(2300 \mathrm{rir})$ lolial Number $4.5 \times 10^{6} \mathrm{im}^{3}(4400 \mathrm{~m})$

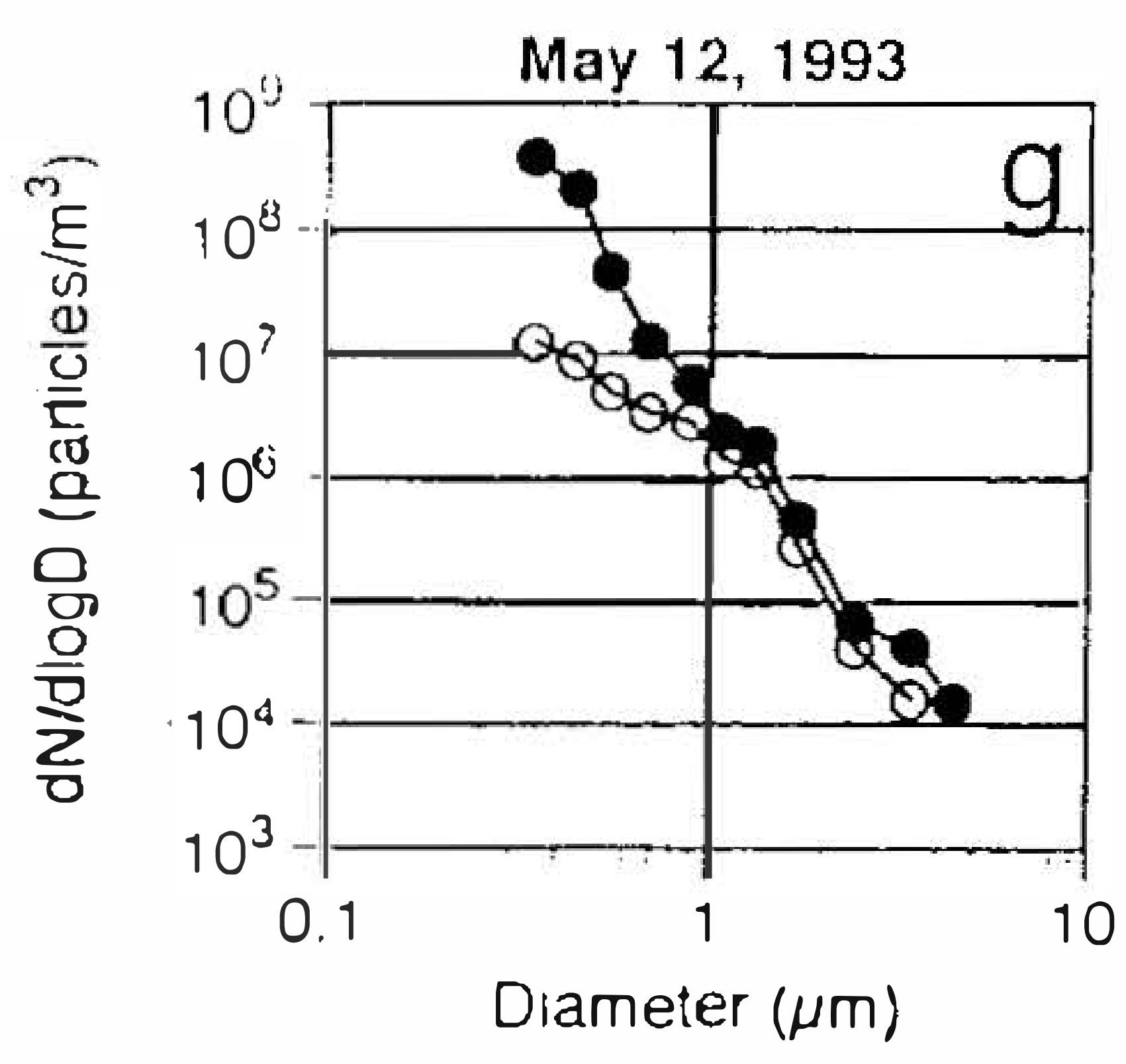

Total Number $7.4 \times 10^{7} / \mathrm{m}^{3}(2300 \mathrm{in})$ Tolal Number $3.8 \times 10^{6} / \mathrm{m}^{3}(4400 \mathrm{~m})$

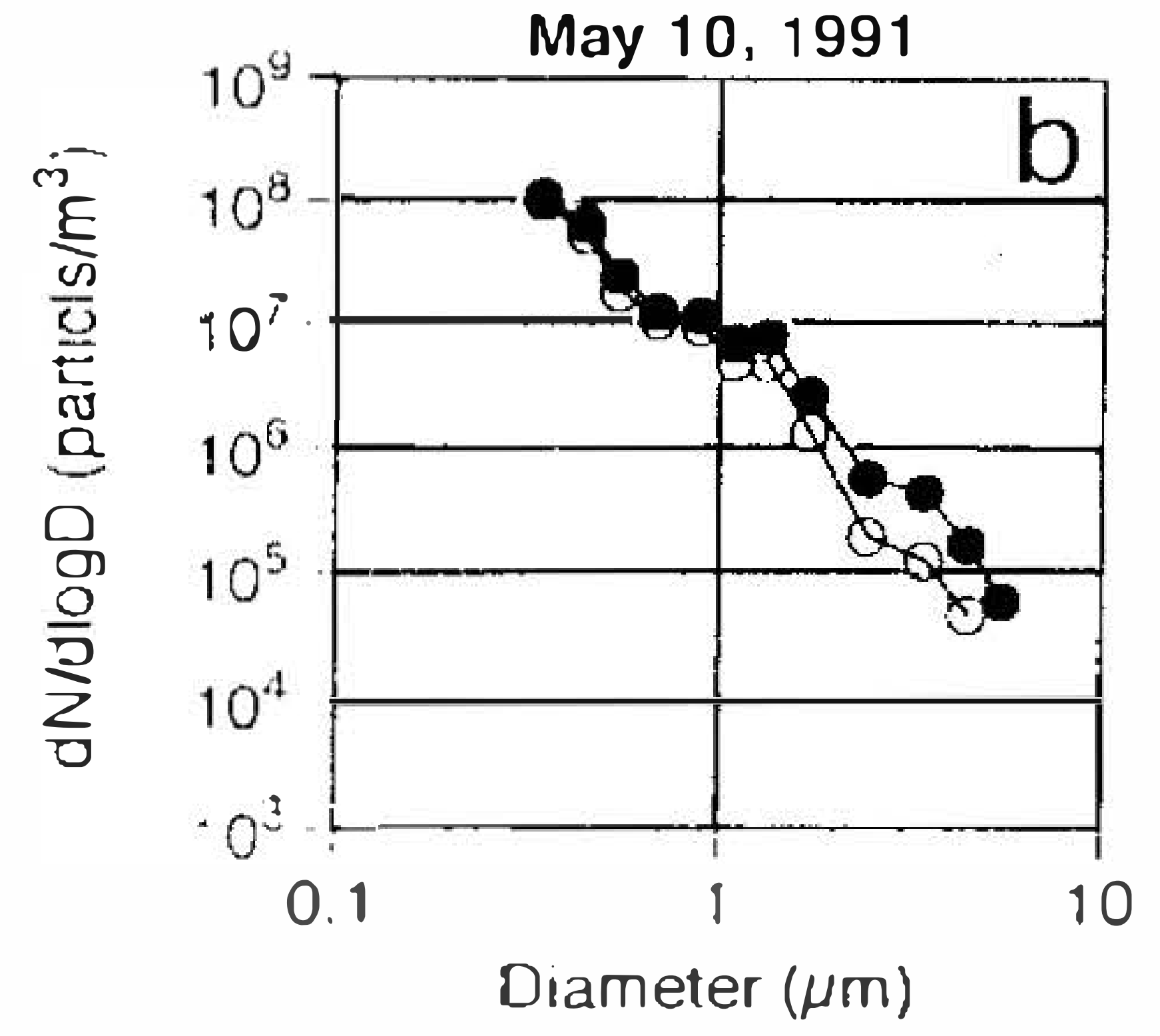

Tutal Number $26 \times 10^{7} / \mathrm{m}^{3}(2300 \mathrm{~m})$ Tolal Number $22 \times 10^{7} / \mathrm{m}^{3}$ (4400 $\left.\mathrm{m}\right)$

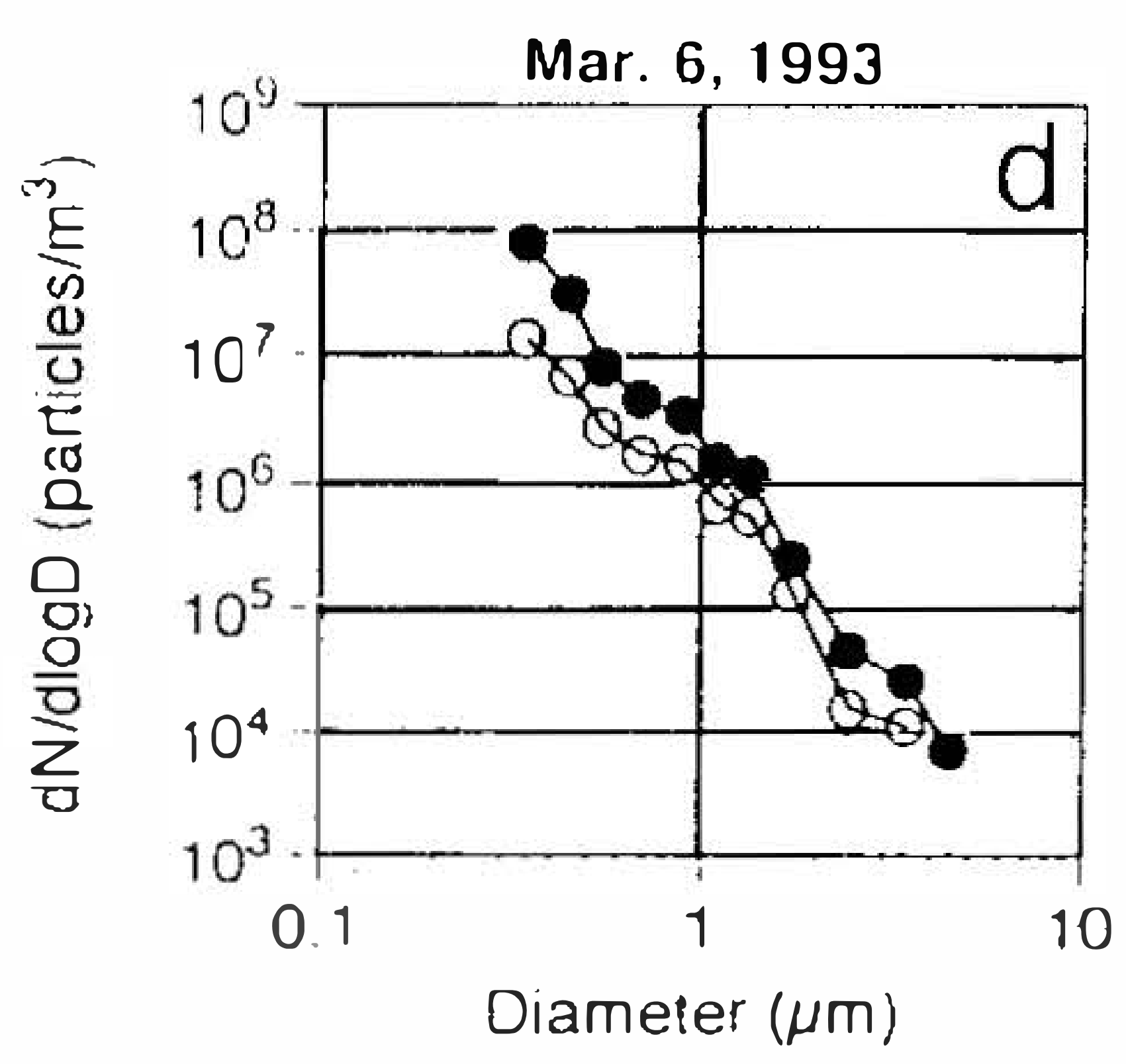

Total Number $1.5 \times 10^{7} / \mathrm{m}^{3}(2300 \mathrm{~m})$ Total Nurnber $3.1 \times 10^{6} / \mathrm{m}^{3}(4400 \mathrm{~m})$

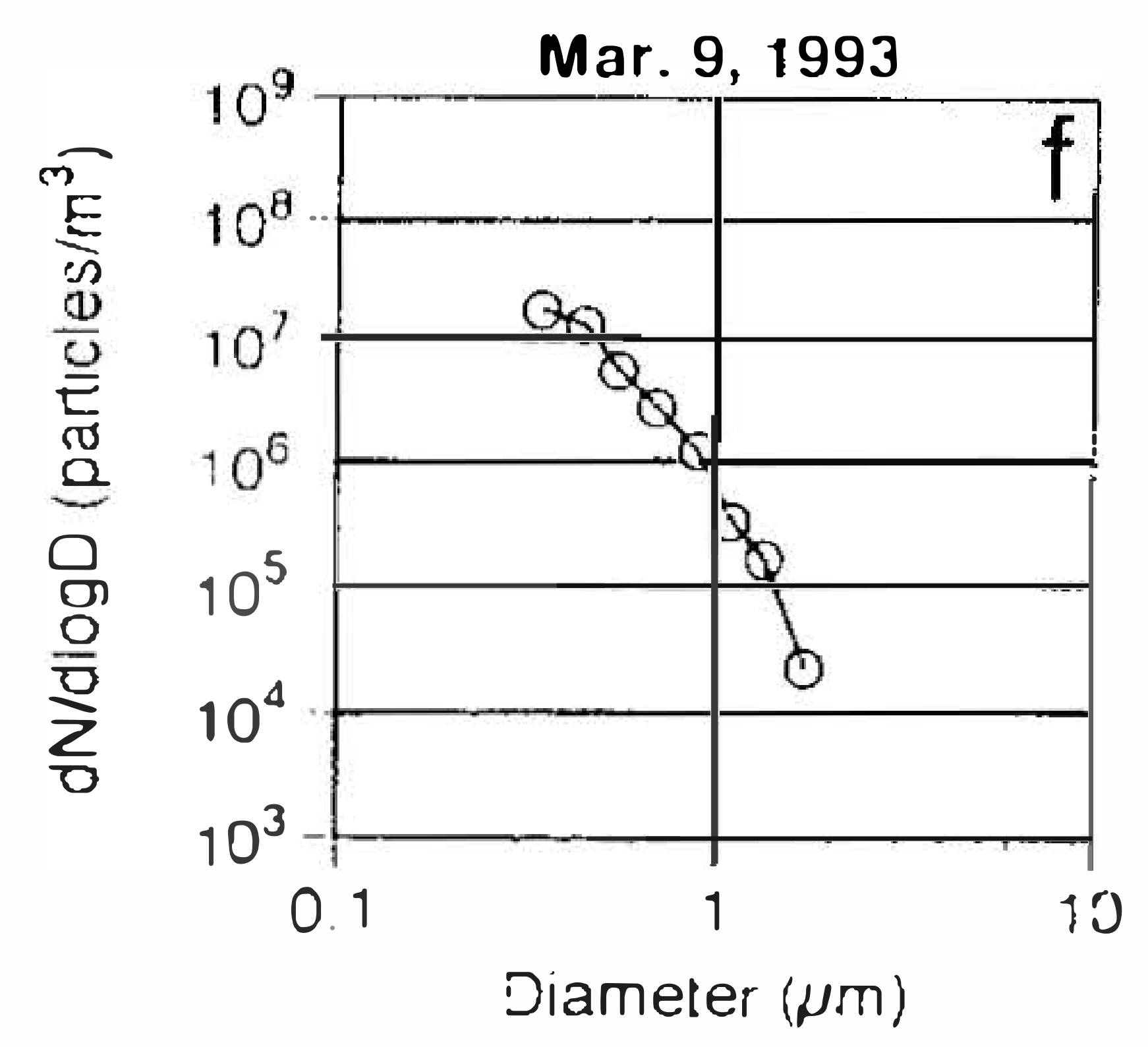

rolal Number $45 \times 10^{6} / 11^{3}(4400 \mathrm{~m})$

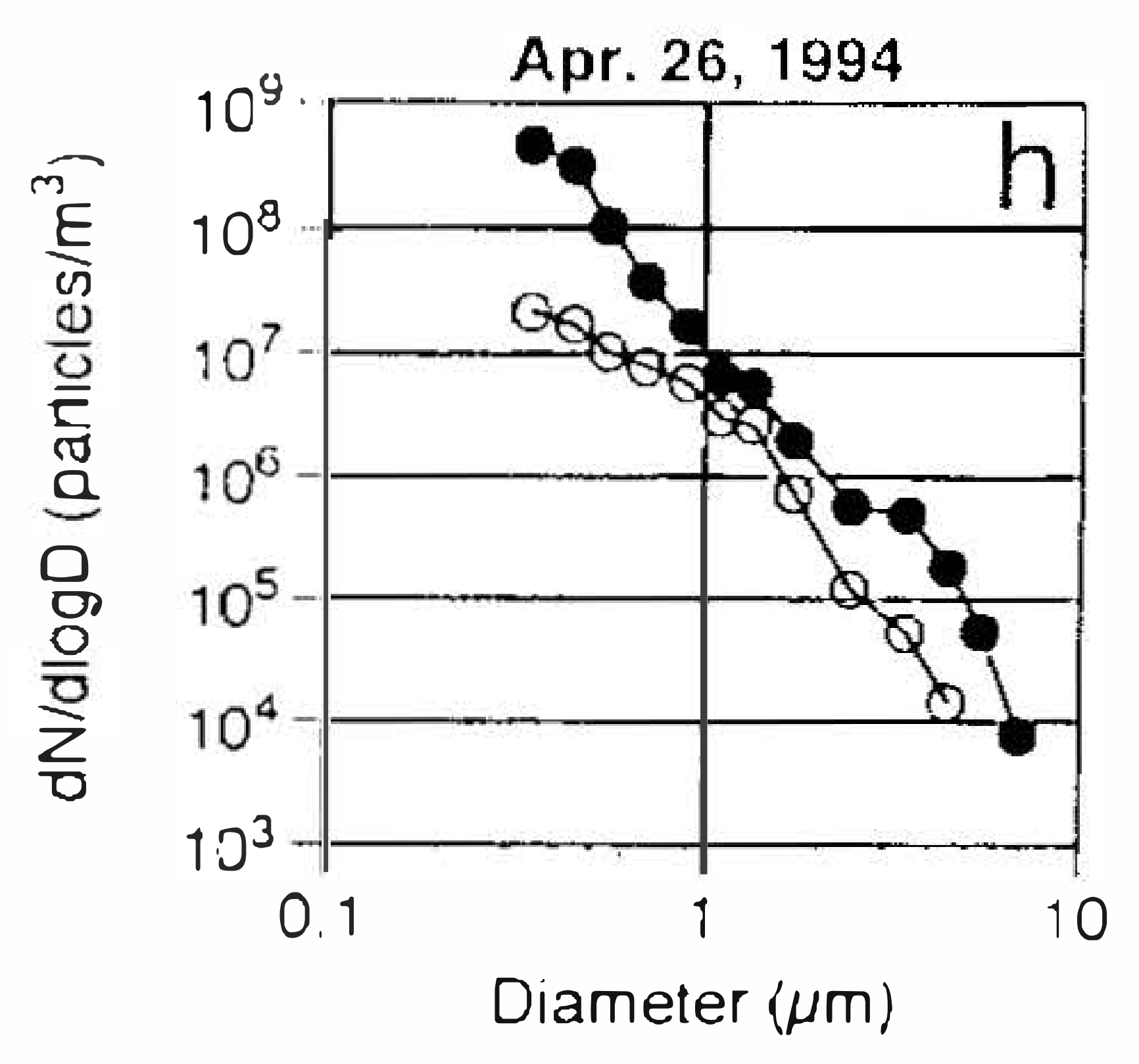

Total Number $1.1 \times 10^{8} / \mathrm{m}^{3}(2300 \mathrm{~m})$ Total Vulnber $7.4 \times 10^{6} \mathrm{~m}^{3}(4400 \mathrm{~m})$

Fig. 2. Number-size distribution function. Measurements were mostly made over the Nagoya-Wakasa Bay area and the Goto Islands area on March 8, 1993. - and o correspond to the measurements at $2.3 \mathrm{~km}$ and $4.4 \mathrm{~km}$, respectively. 
Table 3. Main Characteristics of Lidar.

\begin{tabular}{lll}
\hline Laser & Type: & Nd-YAG \\
& Power: & $1.0 \mathrm{~J} / \mathrm{pluse}$ (Maximum) \\
& Wavelength: & $0.53 \mu \mathrm{m}$ \\
& Pulse Length: & $20 \mathrm{nsec}$ \\
& Repetition of Laser Pulse: & $10 \mathrm{~Hz}$ \\
& & \\
Receiving Telescope & Diameter: & $50 \mathrm{~cm}$ \\
& Type: & Newtonian \\
Detection & Photon couting with photomultiplier \\
\hline
\end{tabular}

Kristament et al. (1993) and Lechner et al. (1989) observed the number-size distribution patterns of the free atmospheric aerosols around New Zealand and over the south west Pacific. A comparison of the present results with those shows the number concentration, $\mathrm{dN} / \mathrm{d} \log \mathrm{D} ; \mathrm{D}=$ diameter, in the diameter range of 0.7-2.0 $\mu \mathrm{m}$ over Japan in spring is 10-100 times of the marine atmospheric particles . Microscopic measurements of particles collected at $4.4 \mathrm{~km}$ frequently identified irregularly shaped particles, possibly soil particles, with a diameter $\geq 10 \mu \mathrm{m}$ (Figure 4). The active transportation of soil particles from the Asian continent to Japan by westerly prevailing winds seems to clearly explain the discrepancy between the results here and those obtained in the marine free atmosphere over the south west Pacific ocean.

The backward trajectory analysis of air mass corresponding to the height of the aerosol layer detected by the lidar was made on the surface of isopotential temperature. The analysis indicates that most of the air mass came from the Asian continent within a few days, as shown in the samples of analyzed trajectories (Figure 5).

This trajectory analysis indicates the possibility that an air mass noticeably moves up and down during the long range travel of the air mass. The large upward motion of the air mass can compensate for the descending movement of the extremely large size particles contained in the ascending air mass, and consequently super micron particles can also travel a long way. As a good example, Betzer et al. (1988) collected giant mineral particles with $\mathrm{D} \geq 200 \mu \mathrm{m}$ which were transported from the Asian continent to the north-west Pacific ocean by strong westerly winds. The present analysis suggests that the upward motion of the air mass containing extremely large particles is an important process for the long range transport of such particles since it is expected that those particles descend rapidly to the ground without such an upwelling motion of air.

It is thought that the peak in the submicron size range is mainly due to aerosols produced through photochemical reactions including atmospheric sulfur emitted in the urban surface atmosphere through human activities (e.g., Okada et al., 1986), transported from the continent over the ocean (Duce et al., 1983), and produced from the oxidation of dimethylsulfide (DMS) in the marine boundary layer (Patterson et al., 1980; Hoppel et al., 1987; Kreidenweis et al., 1991).

\section{MASS-SIZE DISTRIBUTION}

A QCM cascade impactor (Tokyo Direkku Co., Model PC-2) was used to measure the mass-size distributions of aerosol particles (Figures $6 a-d)$. The sizing diameters (50\% cut off 

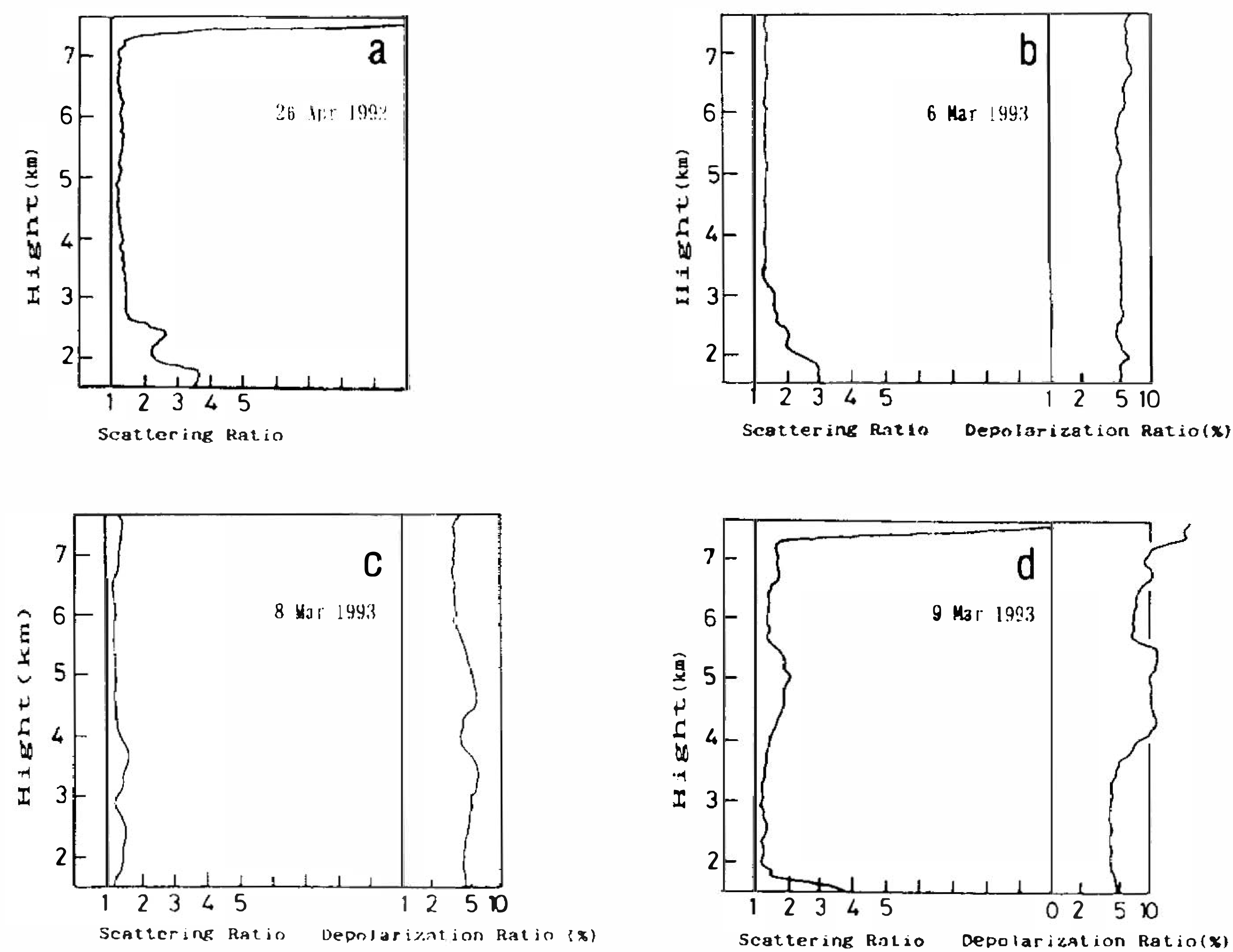

Fig. 3. Scattering ratio and depolarization ratio measured with lidar at Toyokawa corresponding to aircraft measurements in the spring 1992 and 1993. The value of [scattering ratio -1] corresponds to the mixing ratio of particulate matter in the atmosphere (see Text).

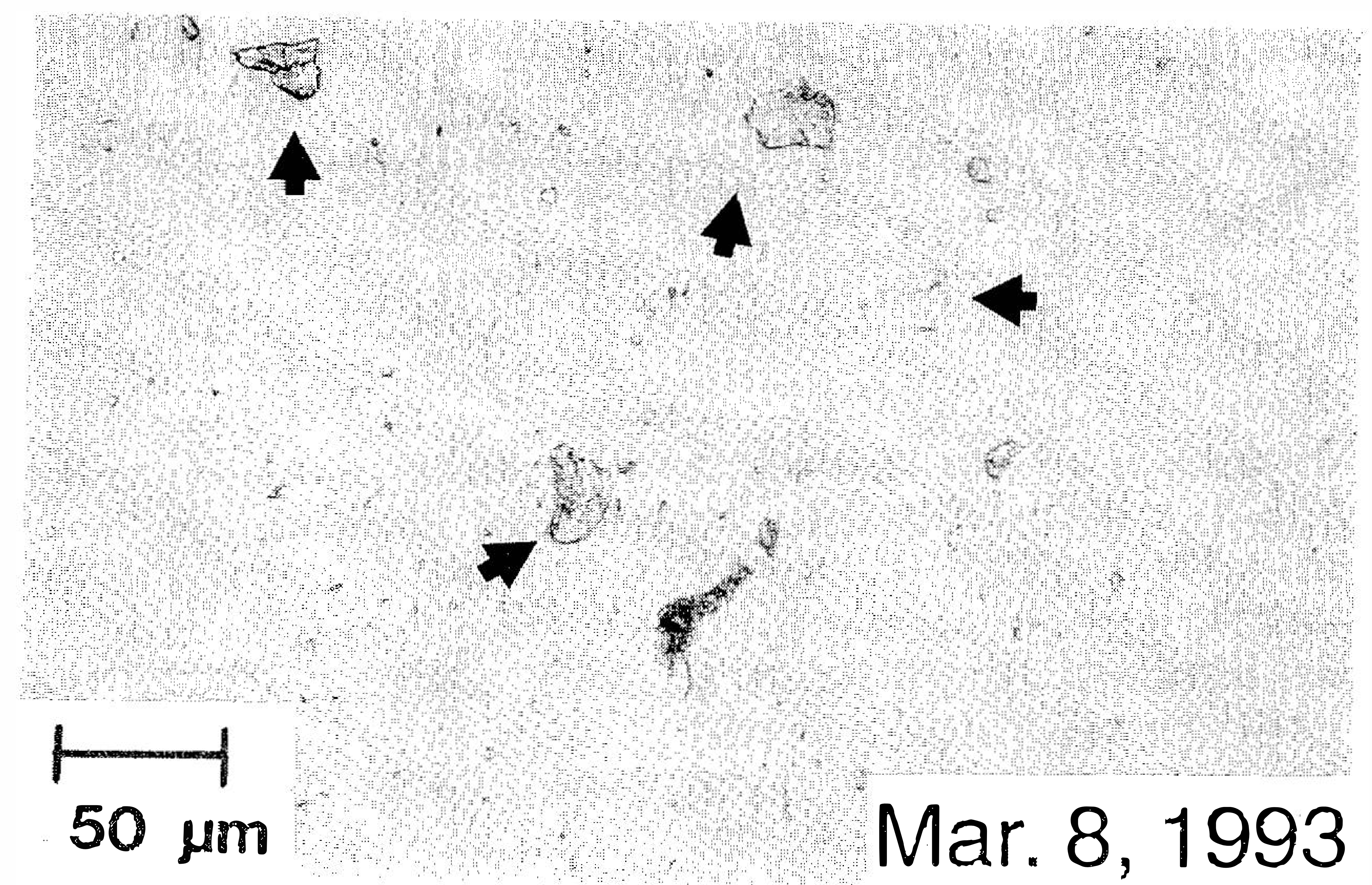

Fig. 4. Particles collected in the free troposphere. Irregular shaped particles (see $\leftarrow)$ were frequently observed during the flight in the free troposphere (4.4 km level). 
diameter) are $0.07 \mu \mathrm{m}, 0.14 \mu \mathrm{m}, 0.28 \mu \mathrm{m}, 0.56 \mu \mathrm{m}, 1.1 \mu \mathrm{m}, 2.3 \mu \mathrm{m}, 4.5 \mu \mathrm{m}, 9.0 \mu \mathrm{m}, 17.6$ $\mu \mathrm{m}$ and $31.3 \mu \mathrm{m}$, for a spherical particle with a density of $1 \mathrm{~g} / \mathrm{cm}^{3}$.

The number-size (or volume-size) distributions of 8 March 1993 are the typical example showing the Kosa effect in the free troposphere (Figures 2 and 7). The enhancement in number density was only detected at $4.4 \mathrm{~km}$ and not at the $2.3 \mathrm{~km}$ level. The mass-size distribution of the $4.4 \mathrm{~km}$ level also showed enhancement which corresponds well the feature found in vertical change in aerosol number concentration. The measurement of the volume spectrum of 12 May 1993 indicated the typical pattern under a relatively calm atmospheric condition in which the aerosol concentration decreased according to the increase in the height for all size ranges observed here. However, the volume-size distribution shows a typical single mode shape, as is frequently observed in the boundary atmosphere during a Kosa episode. The measurements of the mass-size distribution during that day show the enhancement of coarse size particles having a diameter of 9.0-17.6 $\mu \mathrm{m}$ which seems to correspond to the
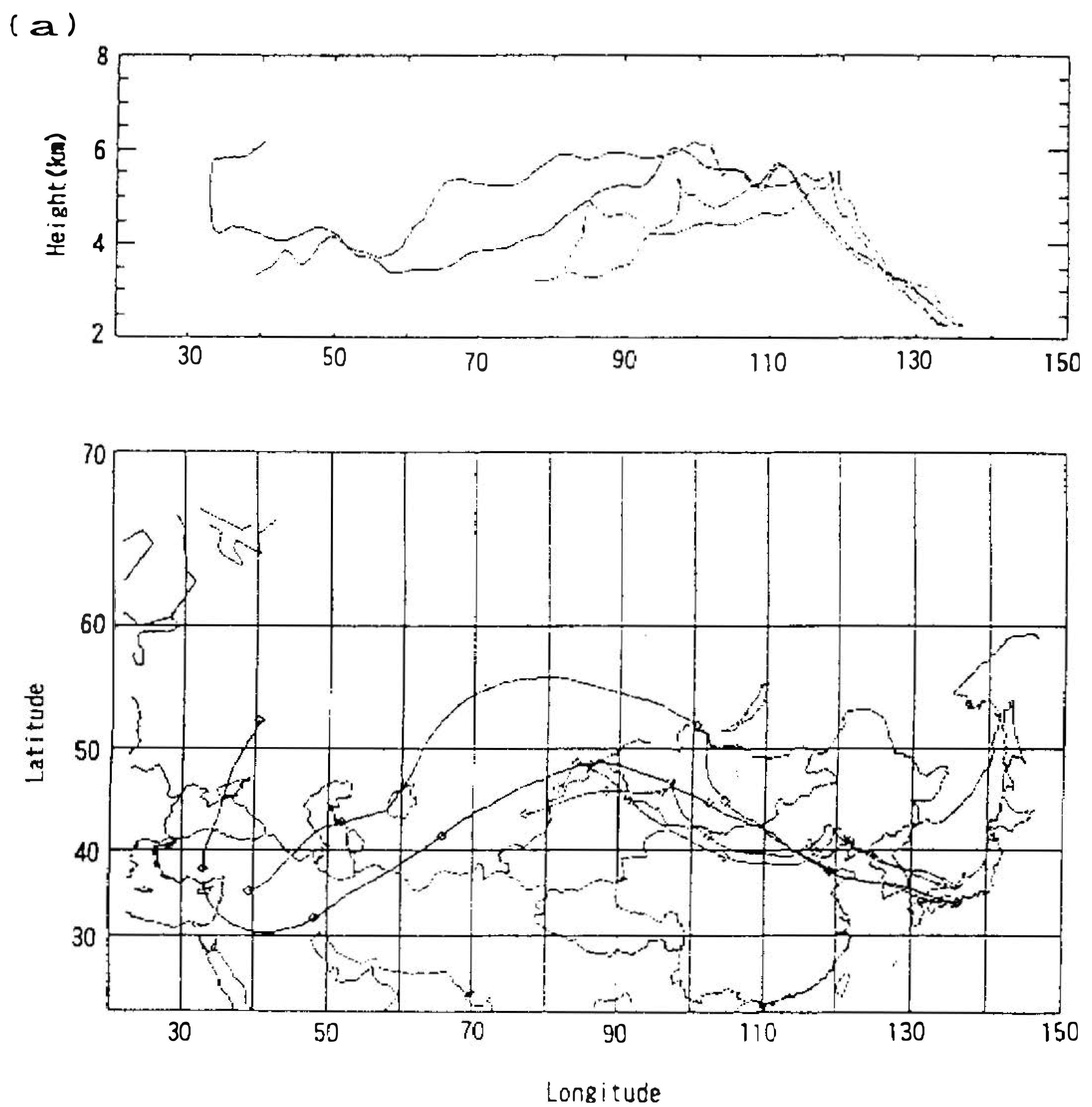

Fig. 5. Example of a 7- (or 4) days backward trajectory analysis of air mass. Data present the initial position of the air mass, height and date

a: $\left(34^{\circ} \mathrm{N}, 134^{\circ} \mathrm{E}\right),\left(36^{\circ} \mathrm{N}, 134^{\circ} \mathrm{E}\right),\left(34^{\circ} \mathrm{N}, 136^{\circ} \mathrm{E}\right),\left(36^{\circ} \mathrm{N}, 136^{\circ} \mathrm{E}\right)$; $2290 \mathrm{~m}$ height; January 8,1992

b: $\left(34^{\circ} \mathrm{N}, 128^{\circ} \mathrm{E}\right),\left(36^{\circ} \mathrm{N}, 128^{\circ} \mathrm{E}\right),\left(34^{\circ} \mathrm{N}, 130^{\circ} \mathrm{E}\right),\left(36^{\circ} \mathrm{N}, 130^{\circ} \mathrm{E}\right)$; $4430 \mathrm{~m}$ height; March 8, 1993

c: $\left(34^{\circ} \mathrm{N}, 128^{\circ} \mathrm{E}\right),\left(36^{\circ} \mathrm{N}, 128^{\circ} \mathrm{E}\right),\left(34^{\circ} \mathrm{N}, 130^{\circ} \mathrm{E}\right),\left(36^{\circ} \mathrm{N}, 130^{\circ} \mathrm{E}\right)$; $2290 \mathrm{~m}$ height; March 8, 1993

d: $\left(34^{\circ} \mathrm{N}, 134^{\circ} \mathrm{E}\right),\left(36^{\circ} \mathrm{N}, 134^{\circ} \mathrm{E}\right),\left(34^{\circ} \mathrm{N}, 136^{\circ} \mathrm{E}\right),\left(36^{\circ} \mathrm{N}, 136^{\circ} \mathrm{E}\right)$; $2290 \mathrm{~m}$ height; February 6, 1994

e: $\left(34^{\circ} \mathrm{N}, 134^{\circ} \mathrm{E}\right),\left(36^{\circ} \mathrm{N}, 134^{\circ} \mathrm{E}\right),\left(34^{\circ} \mathrm{N}, 136^{\circ} \mathrm{E}\right),\left(36^{\circ} \mathrm{N}, 136^{\circ} \mathrm{E}\right)$; $4430 \mathrm{~m}$ height; February 6, 1994 

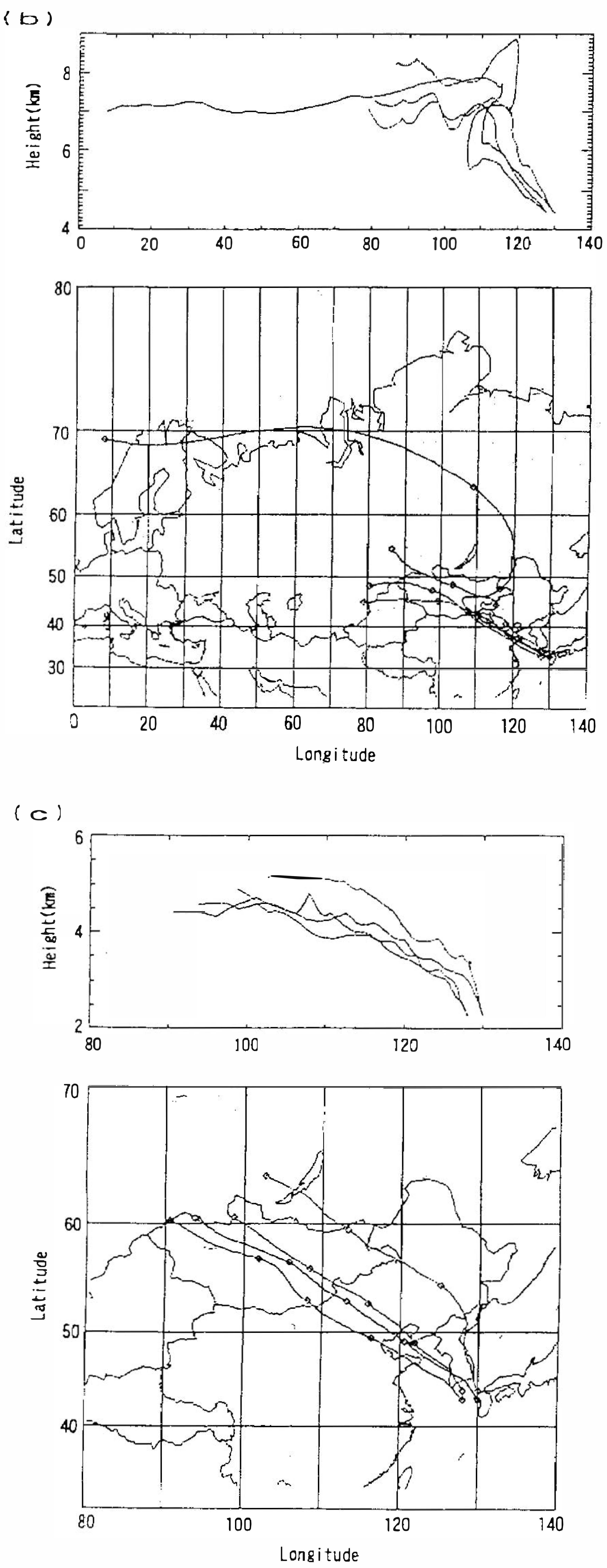

Fig. 5. (Continued) 

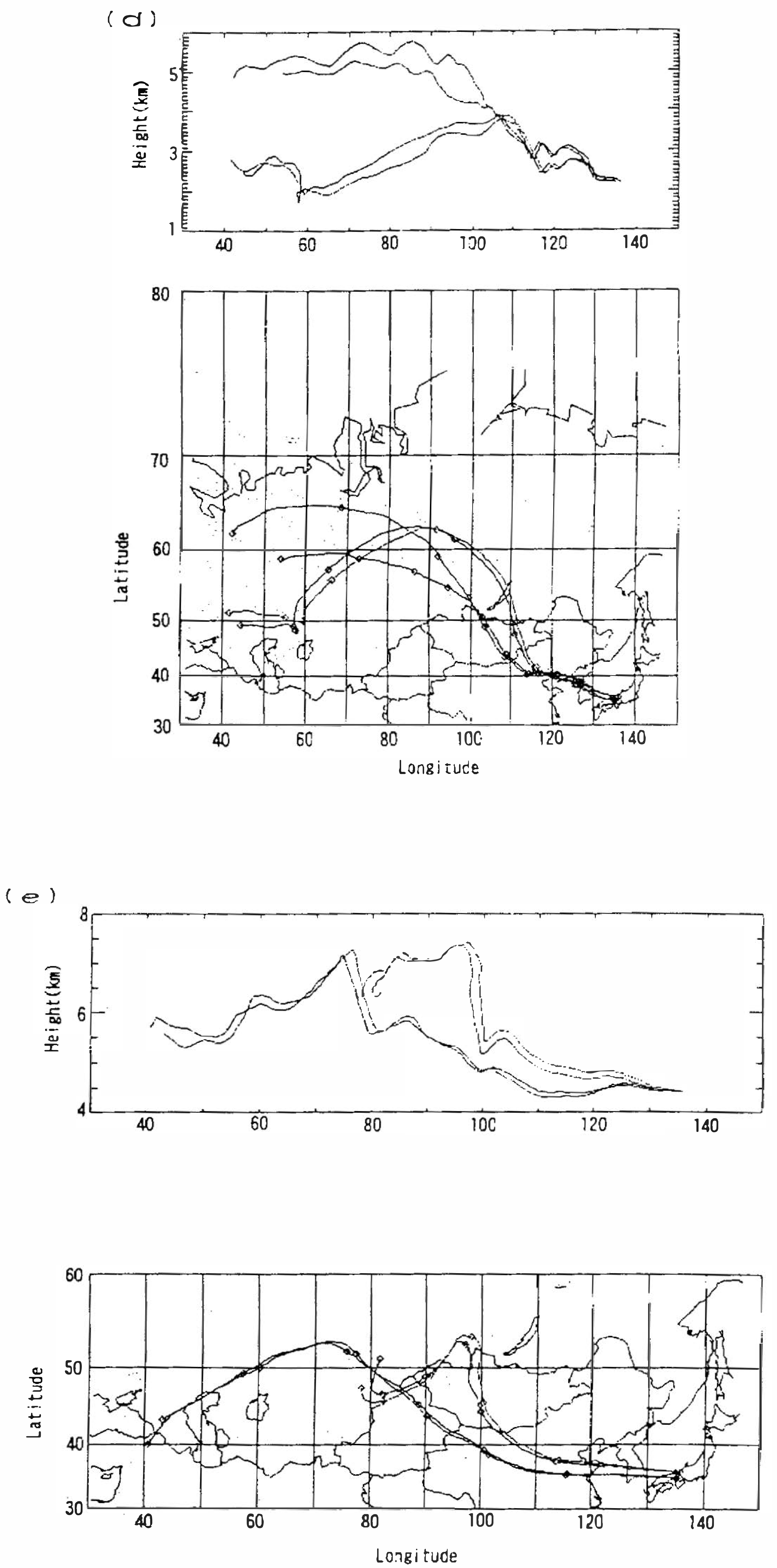

Fig. 5. (Continued) 
volume-size pattern. The concentration of such large particles is so low in the free troposphere that long term collection of particulate matter is necessitated so as to obtain accurate values. The two-hour particle-collection at the flow rate of about $10 \mathrm{l} / \mathrm{min}$ may be insufficient to see the mass-size pattern of a few $\mu \mathrm{m}$ particles in the free troposphere.

Those coarse size particle enhancements in the free troposphere are possibly due to the effect of the long range transport of soil particles even though local meteorological observatories gave no report on Kosa. This is in view of the fact that many investigations suggest the possible contribution of soil particles to the enhancement of coarse particles in the free troposphere over Japan (Iwasaka et al., 1988; Hayasaka et. al., 1990; Tanaka et al., 1990).

\section{VOLUME-SIZE DISTRIBUTION}

Volume-size distributions frequently show a bimodal pattern with the peak mode in the submicron or micron range in the ambient atmosphere (e.g., Prospero et al., 1983). On the basis of measurements of the urban atmosphere with polar nephelometer (Hayasaka et al., 1992), a bimodal volume spectrum is frequently identified.

The residence time of aerosol particles in the atmosphere strongly depends on the particle size, and the density of super micron particles is expected to rapidly decrease with an increase in altitudes owing to the shorter residence time of coarse particles. Airborne polar nephelometer measurements show that the density of coarse particles decreases drastically above the mixed layer in the summer when the Pacific High prevails over Japan (Hayasaka et al., 1990).

During Kosa events, the volume spectra with an enhanced single mode (mode diameter of 2-4 $\mu \mathrm{m}$ ) is observed in the surface atmosphere over Japan (Tanaka et al., 1989; Arao and Ishizaka, 1986). In Figure $7 \mathrm{a}-\mathrm{h}$, the volume-size distribution patterns estimated from the number-size distribution functions as measured with a particle counter are shown. The following features were noticeable while the measurements were being conducted in the spring (March, April, May) of 1991-1994:

(1) two (or three) mode type patterns are sometimes observed at 4.4 and $2.3 \mathrm{~km}$ levels.

(2) single mode function having a mode of coarse range is more frequently observed at 4.4 $\mathrm{km}$ than at $2.3 \mathrm{~km}$.

Based on the observations with a lidar (Iwasaka et, al., 1988) and an airborne polar nephelometer (Hayasaka et al., 1990), some investigations have suggested the possibility that soil particles were frequently transported from the Asian continent into the free troposphere over Japan.

The measurements made over the Goto Islands on the southern area of Japan on Mar. 8, 1993 are a good example in that they show a large enhancement of Kosa particles in the free troposphere, and the disturbance of Kosa at the lower altitude is apparently small. In the measurements of May 12, 1993 and April 26, 1994, typical single mode spectra with a mode diameter of about $1.5 \mu \mathrm{m}$ was observed at the $4.4 \mathrm{~km}$ level, while the bimodal distribution was identified at the $2.3 \mathrm{~km}$ level suggesting a disturbance in the boundary layer. Such stratified layer structure suggests that aerosol concentration above the mixed boundary layer is frequently affected by soil particles transported from the Asian continent. Therefore, it is speculated that the Kosa episode observed near the surface was caused not only by sedimentation of individual larger particles during the Kosa appearance in the free 

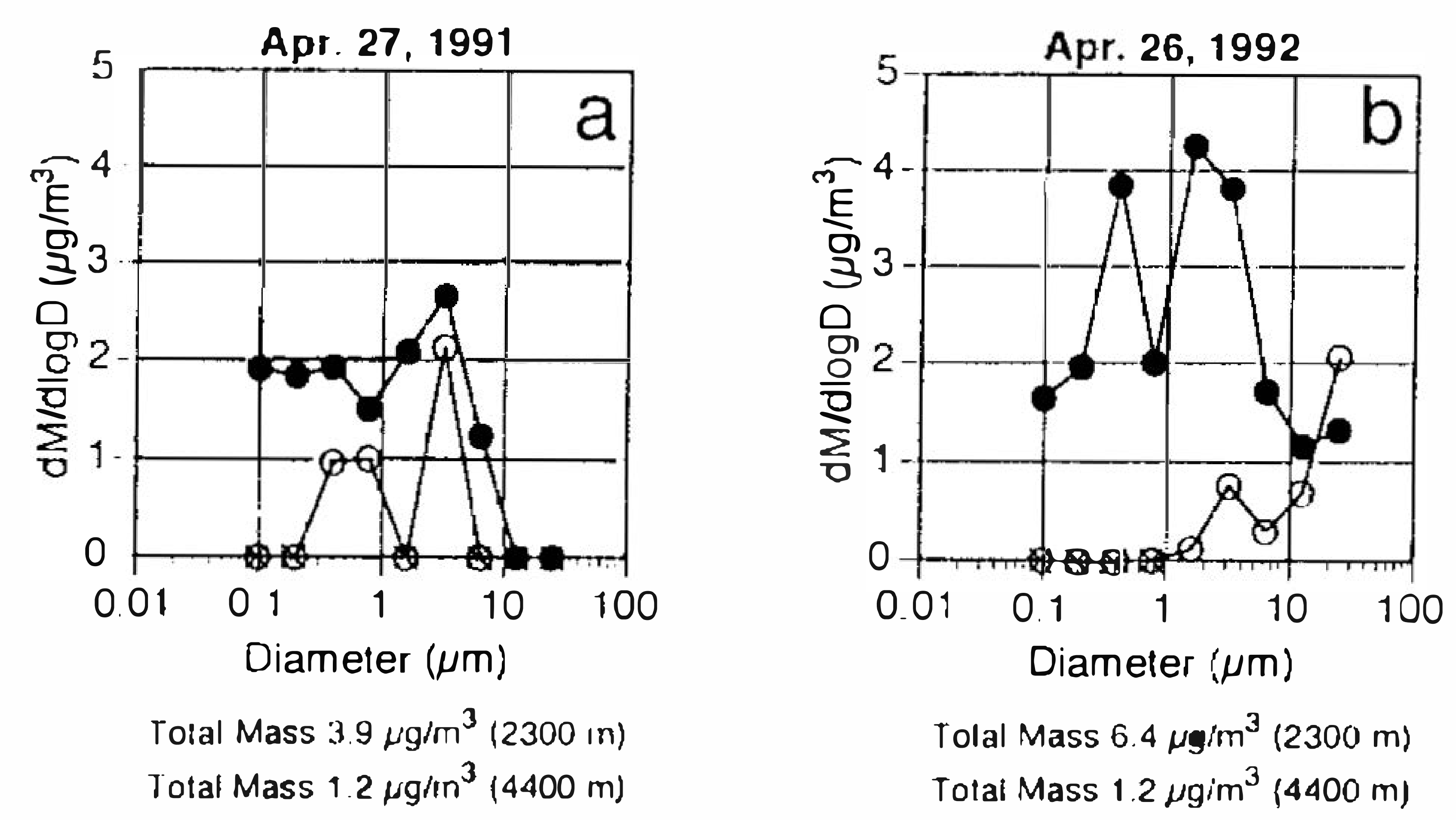

Tolal Mass $6.4 \mu \mathrm{g} / \mathrm{m}^{3}(2300 \mathrm{~m})$

Total Mass $1.2 \mu \mathrm{gim}^{3}\{4400 \mathrm{~m})$
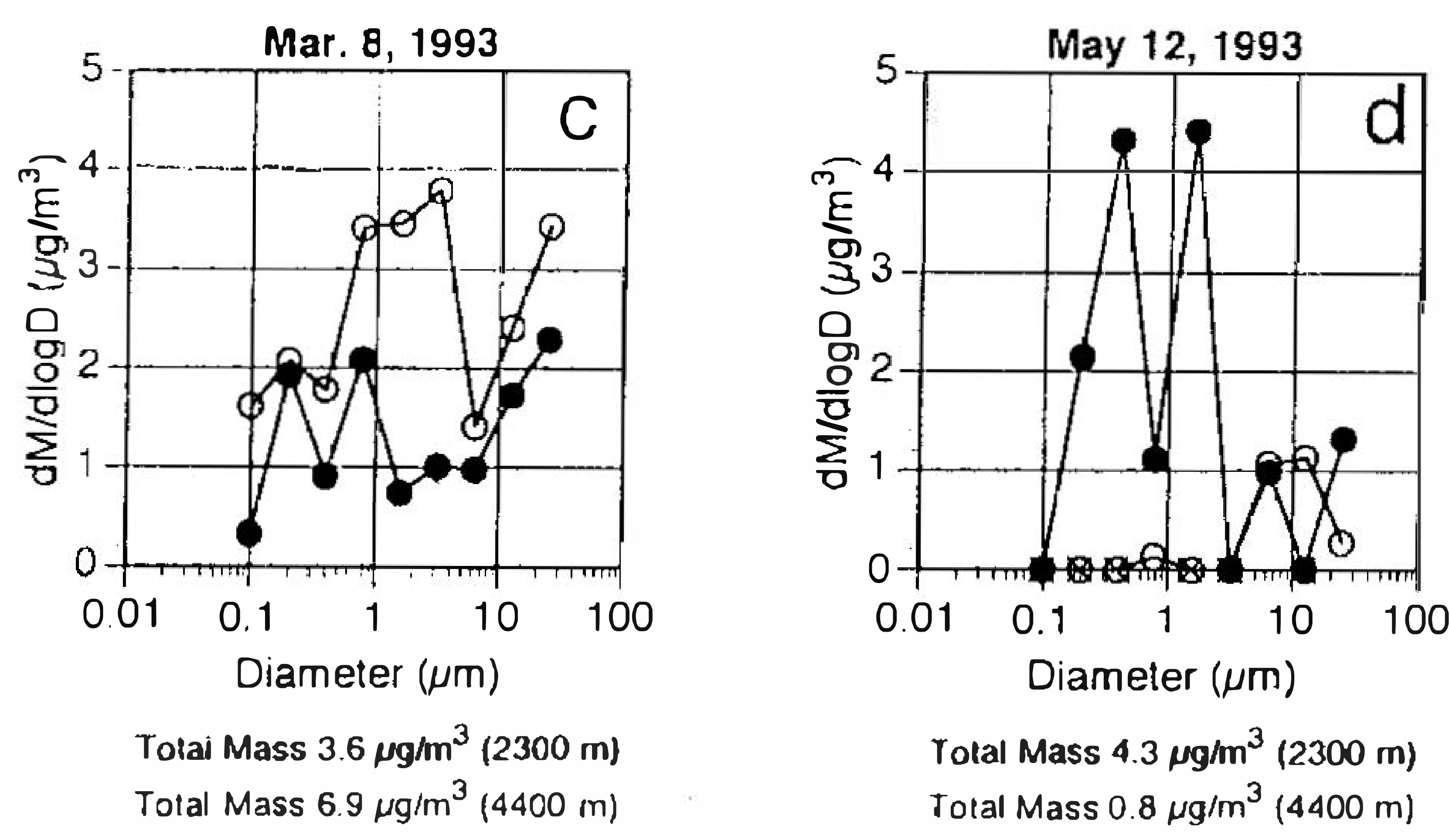

Fig. 6. Sample of the mass-size distribution function observed with an airborne QCM cascade impactor. - and o correspond to the measurements at 2.3 $\mathrm{km}$ and $4.4 \mathrm{~km}$, respectively. $\&$ means density is lower than the detection limit.

troposphere, but also by the descending motion of an air mass containing lots of Kosa particles. It is necessary to discuss the detailed movement of an air mass to clarify this idea.

\section{ENHANCEMENT OF AEROSOL LOAD IN THE FREE TROPOSPHERE}

As shown in Figures 2 and 7, the number and volume concentration of particulate matter observed at about $4.4 \mathrm{~km}$ was higher than that at $2.3 \mathrm{~km}$ in the particle size range larger than $0.54 \mu \mathrm{m}$. The inversion in the vertical distribution of particulate matter concentration can be hardly expected when the content of the relatively large size aerosols is due to only local ground sources (land or sea surface).

The vertical profile of the scattering ratio measured with a lidar on March 8, 1993 shows a broad peak at 2-3 km and 3-4 km (Figure 3). The large depolarization ratio at 4.5 and 3.5 $\mathrm{km}$ suggests the existence of nonspherical particles, such as Kosa particles.Combining the vertical distribution of the scattering ratio of particles and the depolarization ratio, the broad peaks of scattering ratio are thought to be an aerosol layer containing nonspherical particles, such as soil particles. This feature corresponds to the observation of a particle counter which showed that the enhancement of the aerosol load only at $4.4 \mathrm{~km}$ and not at $2.3 \mathrm{~km}$ (Figures $2 \mathrm{e}$ and $7 \mathrm{e} ; 8)$. 


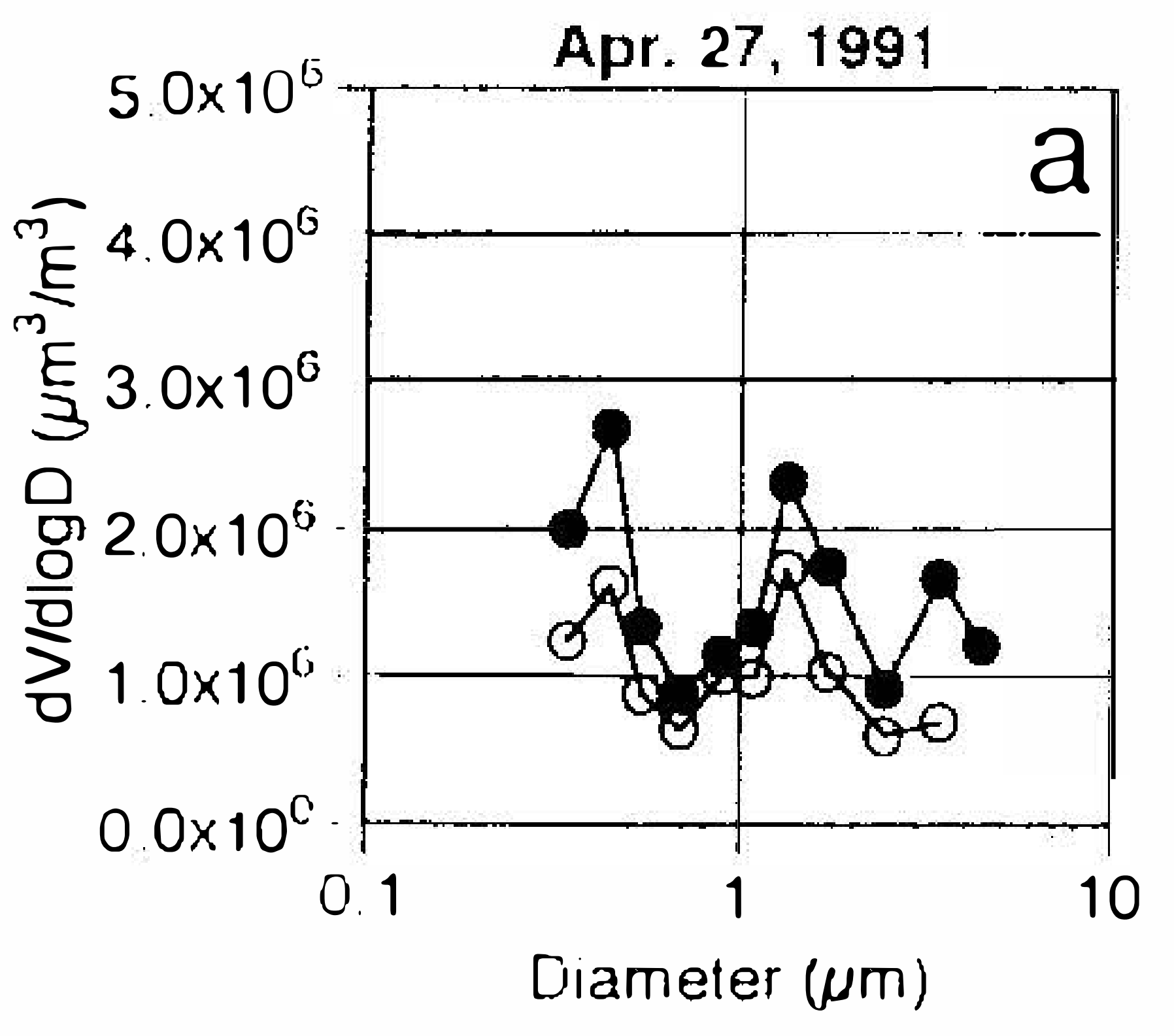

Tolal Volume $1.9 \times 10^{6} \mathrm{\mu m}^{3} / \mathrm{m}^{3}(2300 \mathrm{~m})$ Tolal Volume $1.1 \times 10^{6} \mathrm{~mm}^{3} / \mathrm{m}^{3}$ (4400 m)

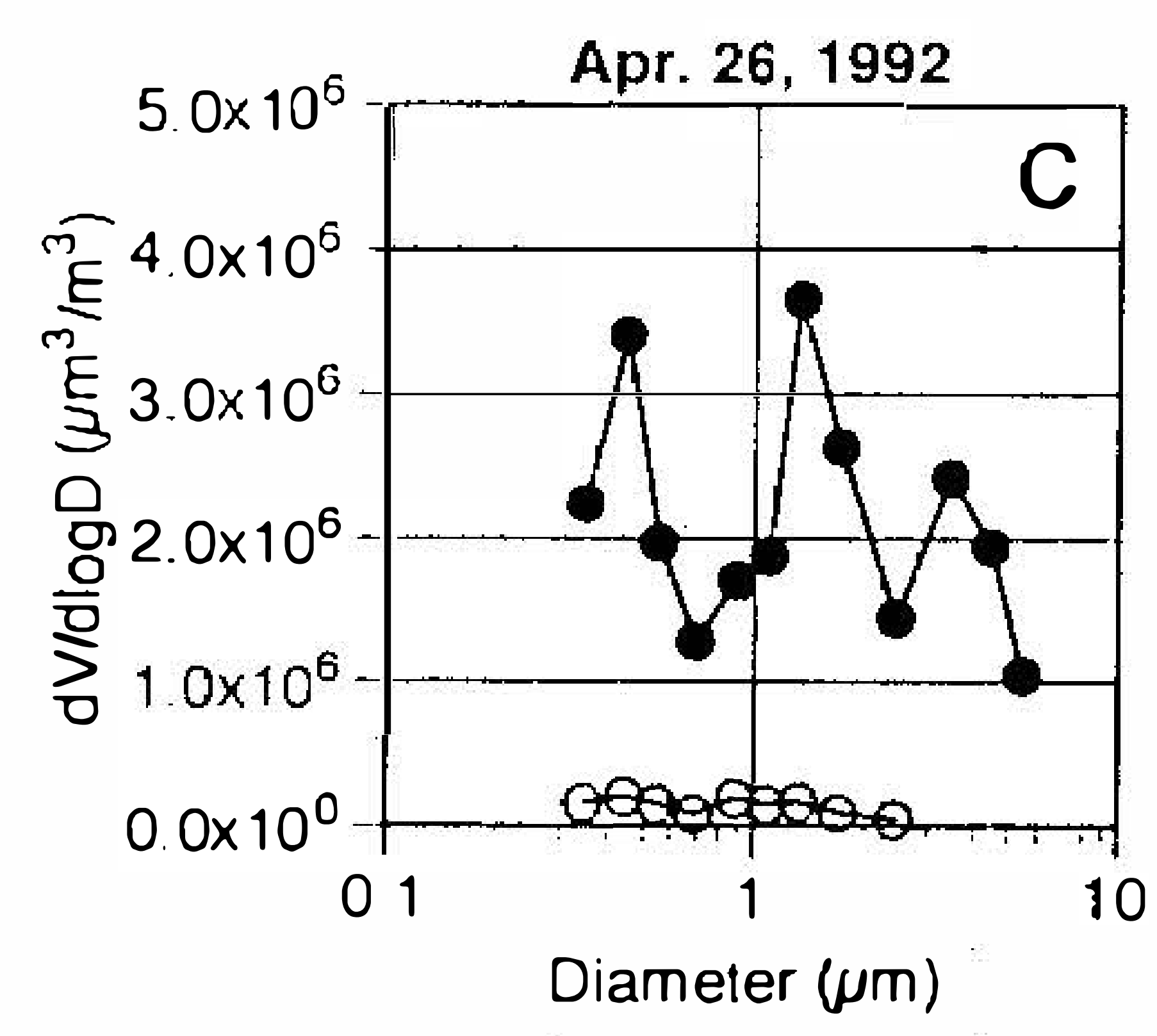

Tolal Volume $2.7 \times 10^{6} \mu^{3} / \mathrm{m}^{3}(2300 \mathrm{~m})$ Tolal Volume $1.3 \times 10^{5} \mathrm{\mu m}^{3} / \mathrm{m}^{3}(4400 \mathrm{~m})$

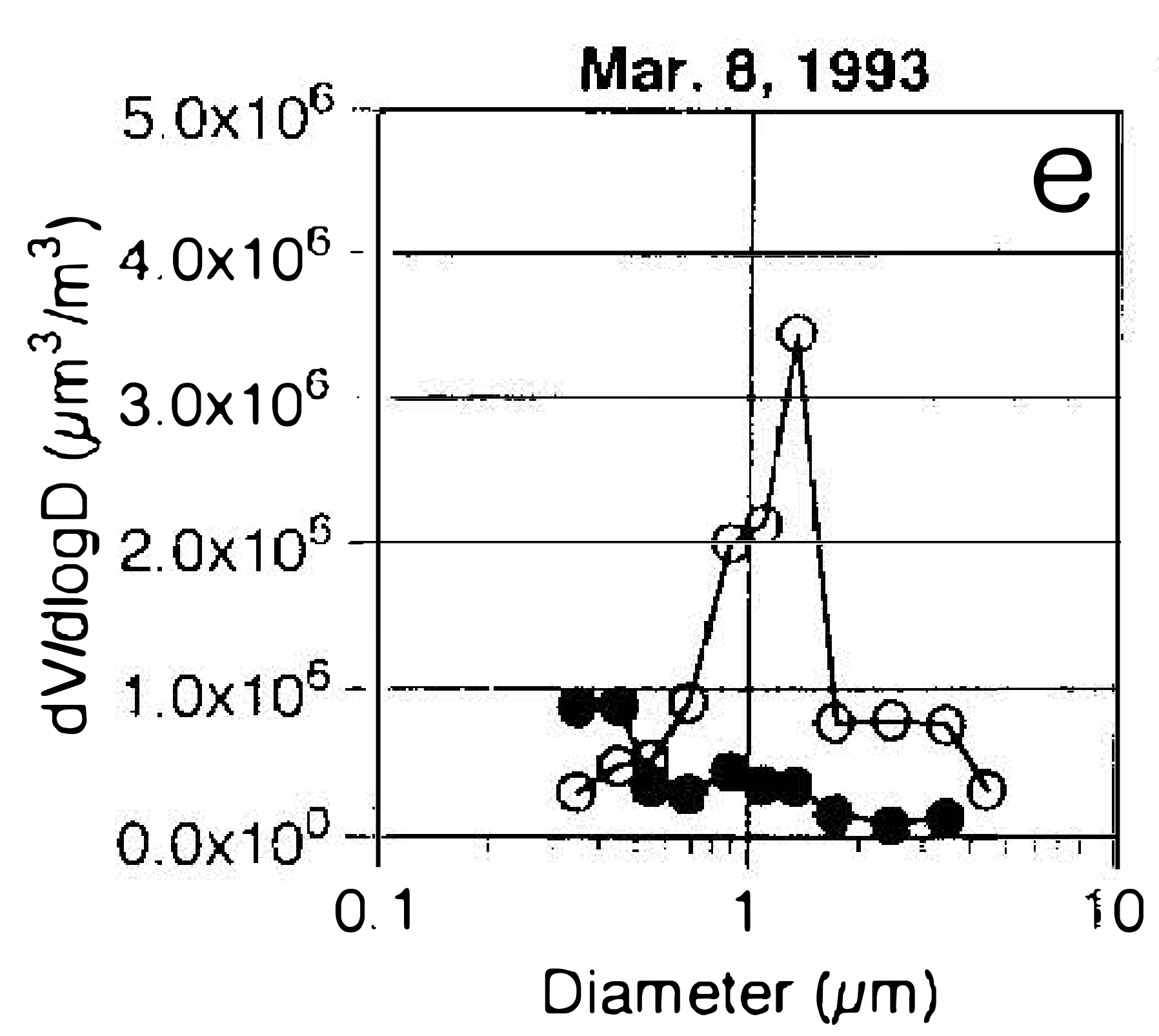

Total Volume $4.1 \times 10^{5} \mathrm{\mu m}^{3} / \mathrm{m}^{3}(2300 \mathrm{~m})$ Tolal Volume $1.3 \times 10^{6} \mathrm{~mm}^{3} / \mathrm{m}^{3}(4400 \mathrm{~m})$

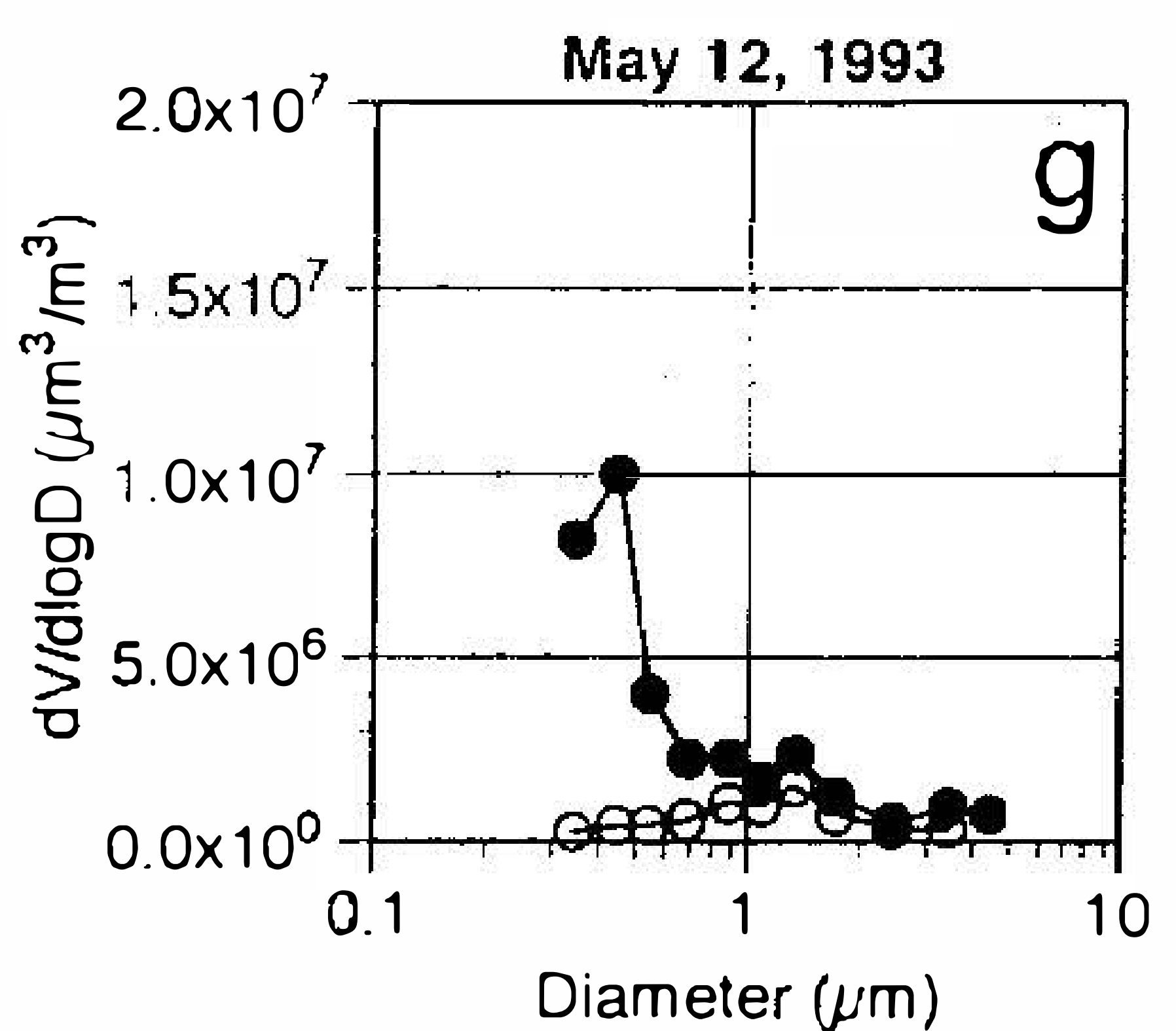

Tolal Volume $3.6 \times 10^{6} \mu \mathrm{m}^{3} / \mathrm{m}^{3}(2300 \mathrm{~m})$ Tolal Volume $7.0 \times 10^{5} \mu \mathrm{m}^{3} / \mathrm{m}^{3}$ (4400 m)

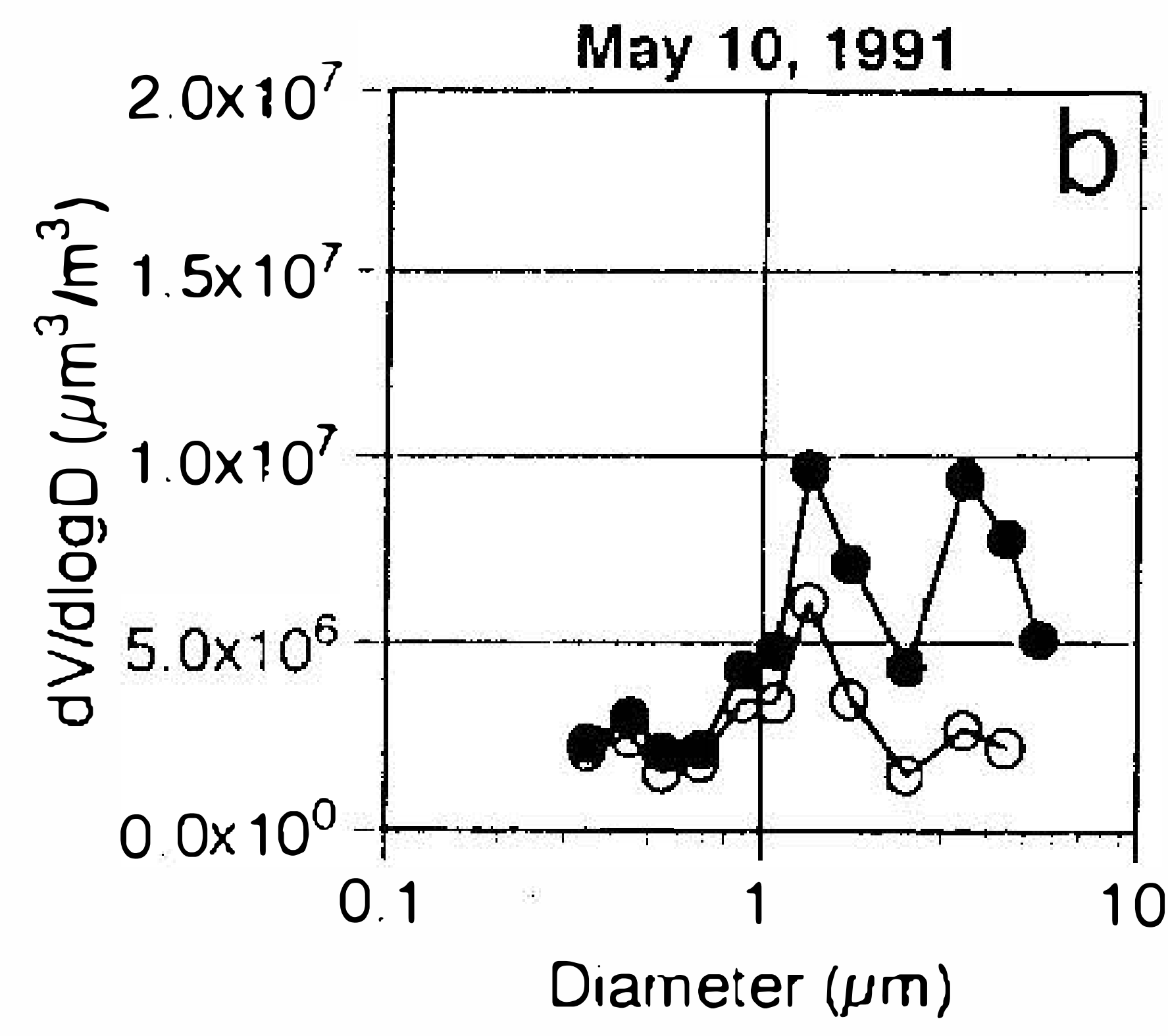

rotal Volume $6.7 \times 10^{6} \mathrm{\mu m}^{3} / \mathrm{m}^{3}(2300 \mathrm{~m})$ Tolal Volume $3.3 \times 10^{6} \mathrm{jrm}^{3} / \mathrm{m}^{3}(4400 \mathrm{~m})$

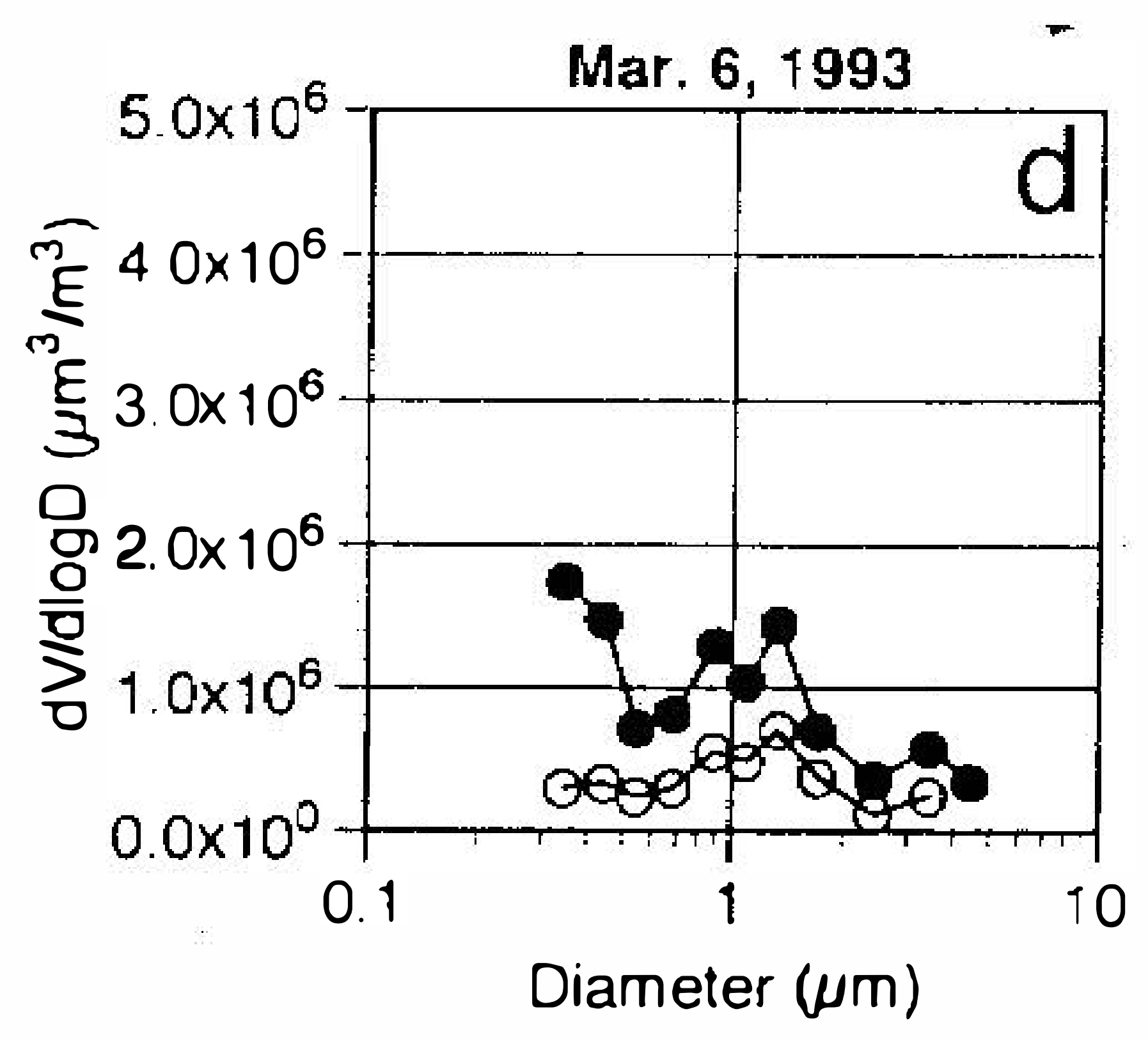

Total Volume $1.1 \times 10^{6} \mathrm{\mu m}^{3} / \mathrm{m}^{3}(2300 \mathrm{~m})$

Total Volume $3.8 \times 10^{5} \mathrm{\mu m}^{3} / \mathrm{m}^{3}(4400 \mathrm{~m})$

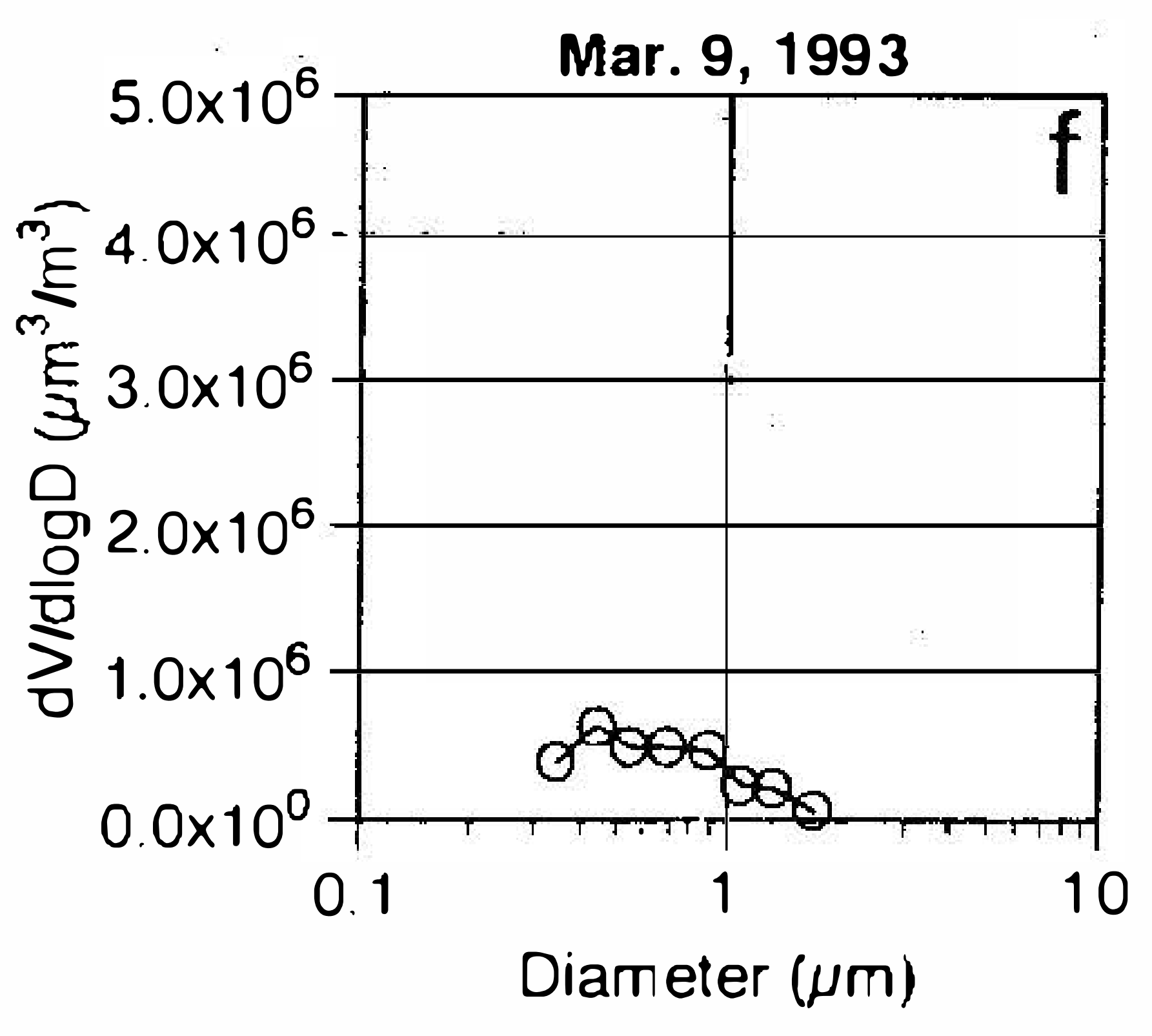

Total Volume $3.0 \times 10^{5} \mu \mathrm{m}^{3} / \mathrm{m}^{3}(4400 \mathrm{~m})$

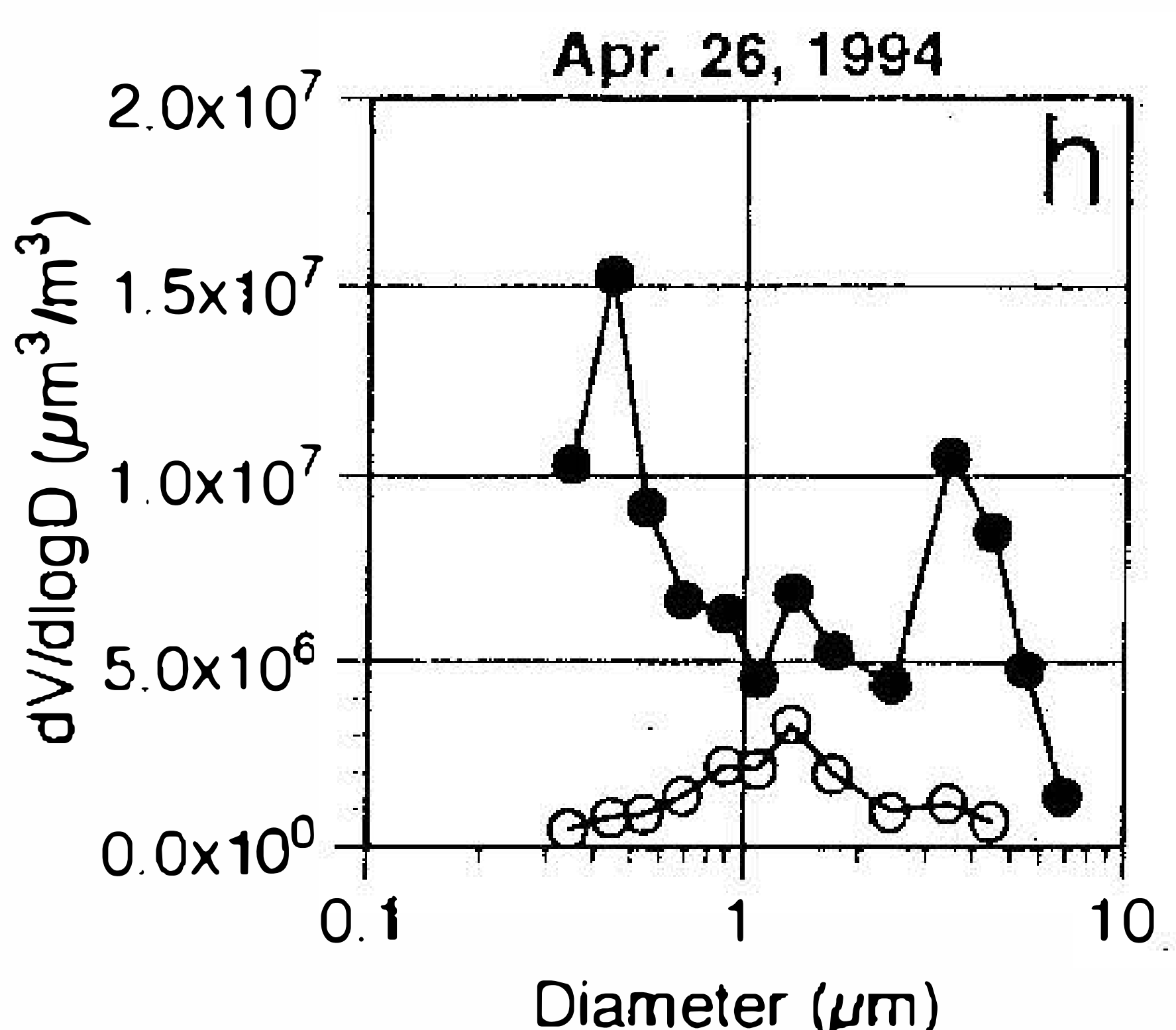

Total Volume $1.0 \times 10^{7} \mu^{3} / \mathrm{m}^{3}(2300 \mathrm{~m})$ Tolal Volume $1.7 \times 10^{6} \mathrm{\mu m}^{3} / \mathrm{m}^{3}(4400 \mathrm{~m})$

Fig. 7. Volume-size distribution function estimated from number-size distribution function shown in Fig. 2. $\bullet$ and o correspond to the measurements at 2.3 $\mathrm{km}$ and $4.4 \mathrm{~km}$, respectively. 


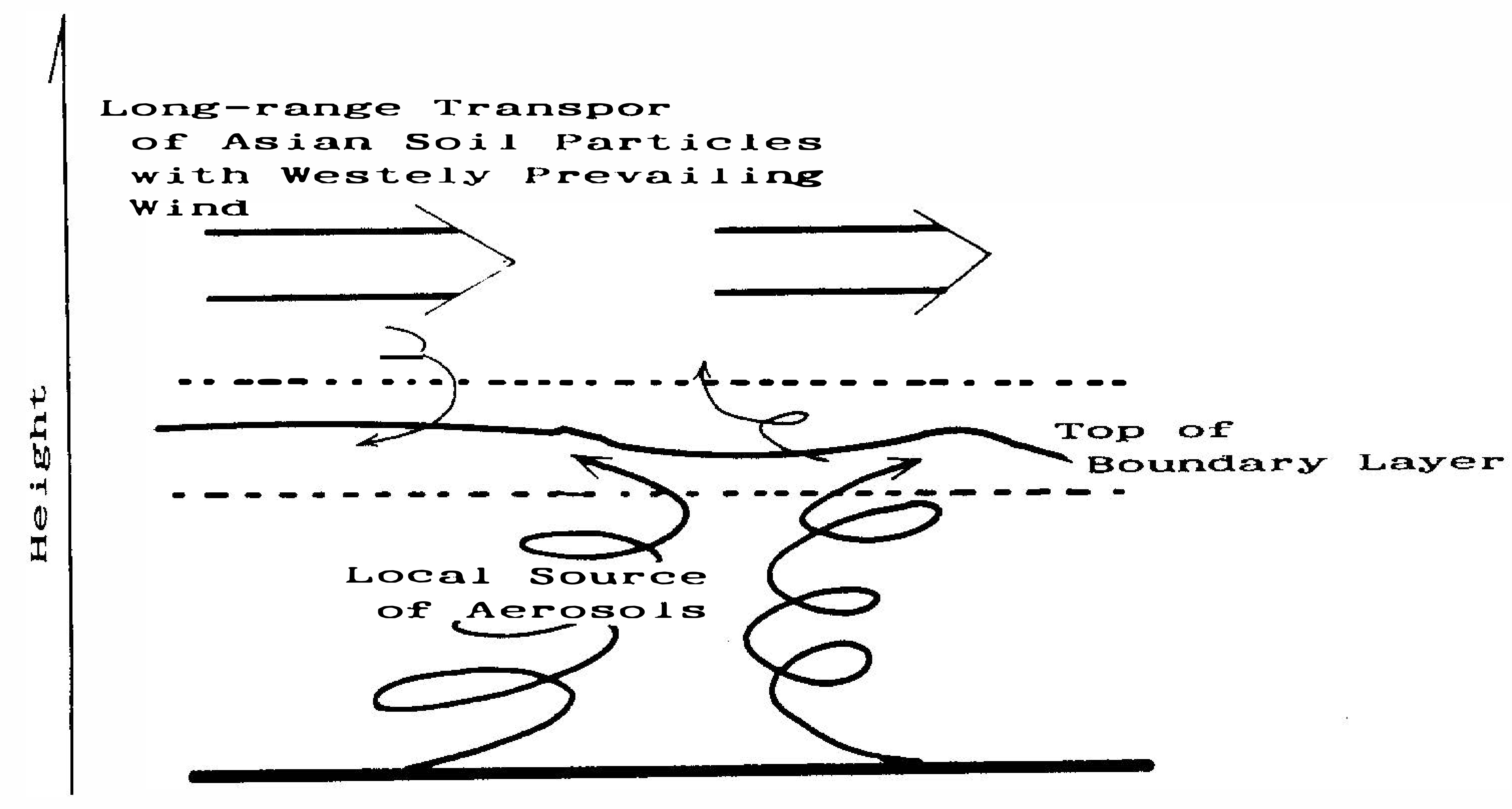

Fig. 8. Kosa (Asian dust particle) effect in the free troposphere. Effects of local source on the aerosol size distribution function are observed when the top of the boundary layer is higher than the height of the level of flight. The value obtained at $2.3 \mathrm{~km}$ was affected by the local source when the top of the layer was higher than $2.3 \mathrm{~km}$. In the free troposphere, westerly wind frequently transports soil particles, and the aerosol load increases during the period when long-range transport of Kosa is active.

In addition to the appearance of free tropospheric aerosol enhancement, enhencements of the aerosol load in the free troposphere were observed several times in fall and winter as well. The feature of a number-size distribution function obtained at those times were very similar to the functions observed during a weak Kosa event in the spring-time, as shown in Figure 9. Figures $9 \mathrm{a}$ and $9 \mathrm{c}$ illustrate the case where free tropospheric aerosol density (4.4 $\mathrm{km})$ was higher than the values of the lower atmosphere $(2.3 \mathrm{~km})$, and the curves in Figure $9 \mathrm{~b}$ indicate the small enhancement of about $1 \mu \mathrm{m}$ in size distribution. Considering that the strong westerly wind also prevails in fall and winter (Kawahara, 1992, 1993; Takano, 1994) the enhancement aerosol load in these seasons is also due to the long range transport of soil particles from the Asian continent. However, the ground condition and activity of atmospheric convection at the source region of soil should vary from season to season. Additionally, global wind system changes from season to season, and the westerly wind passing through Japan has a north component in fall and winter. Hayasaka et al. (1990) suggested that there is a different mechanism of injecting soil particles into the free troposphere between in the spring and winter seasons. Pointing the role played by the Tibetan Plateau in forming strong baroclinity at the east side of the plateau.

However, the present measurements are not complete enough to permit a discussion of seasonal changes in free tropospheric aerosol load. More detailed observations are necessary to study the relationship of the injection processes of soil particles into the free troposphere over the source region, the transport processes of those particles, the spacial and temporal changes in source strength and the changes in the global wind system affecting the long range transport of the particles. 


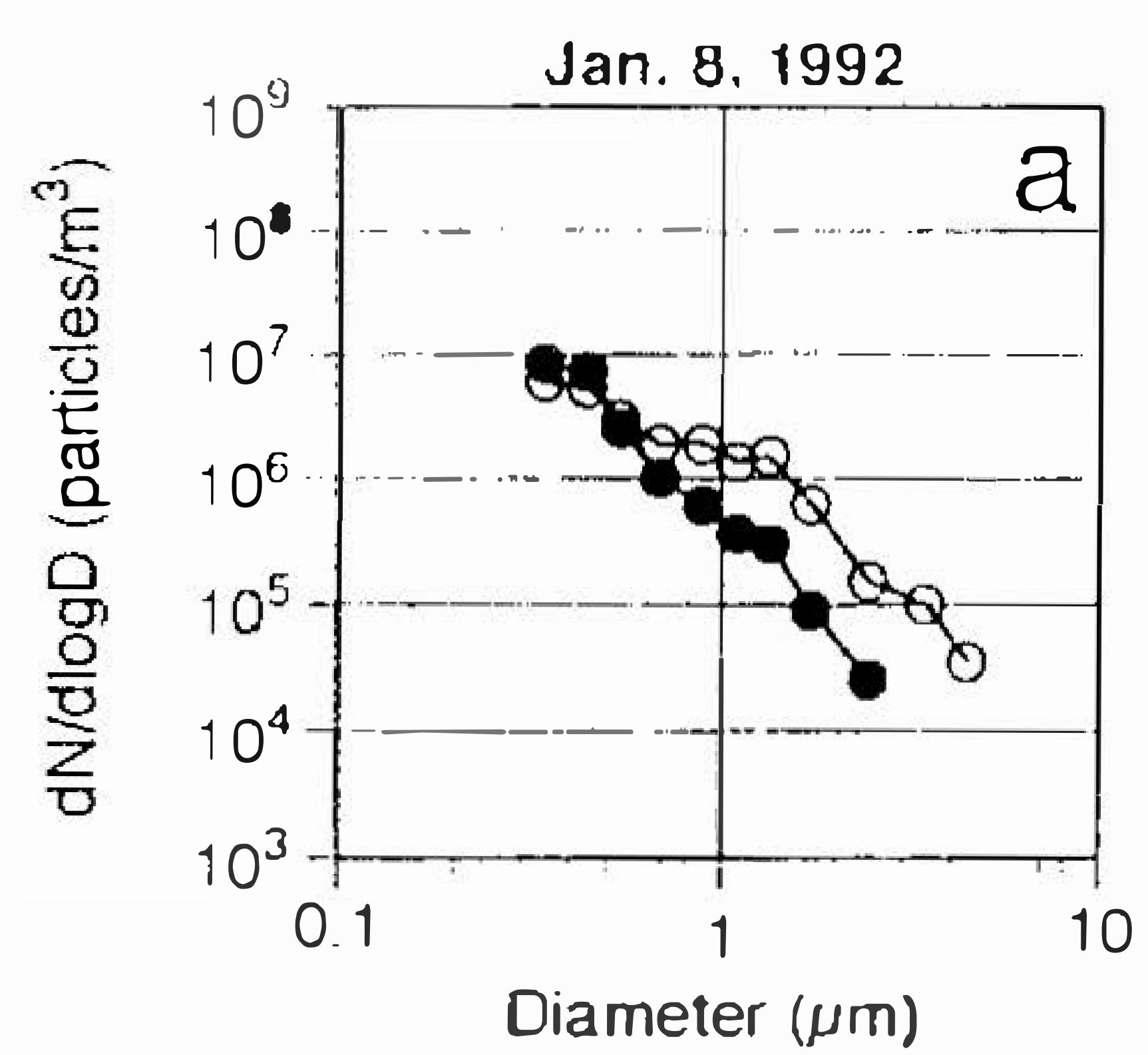

Tolal s Juinuer $2.2 \times 10^{E} / \pi^{3}(23 \mathrm{C} .0 \mathrm{~m})$ rolall Number $2.3 \times 10^{\mathrm{E}} / \mathrm{m}^{3}(14 \mathrm{CO} \mathrm{m})$

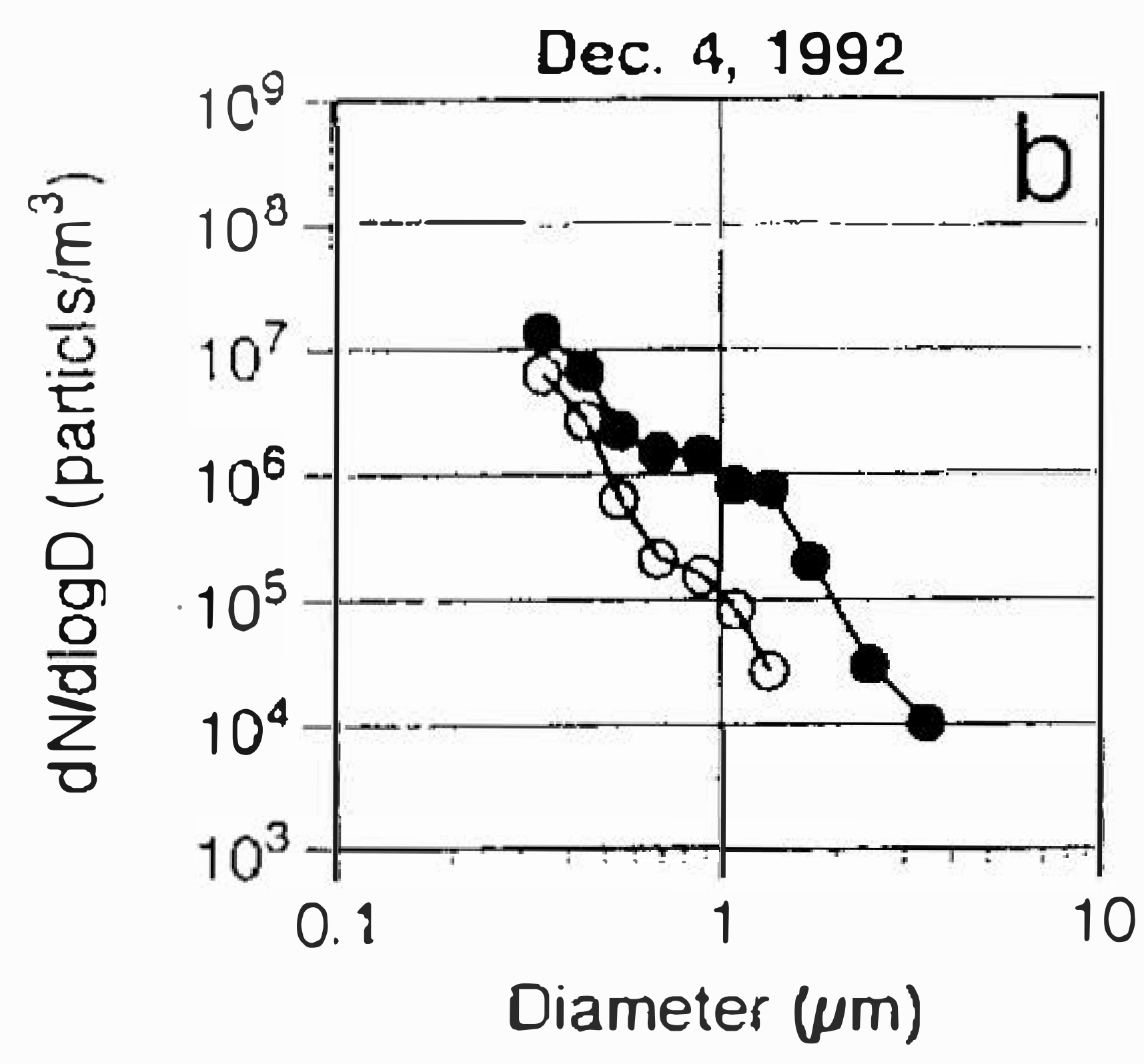

Total Number $3.1 \times 10^{6} / \mathrm{m}^{3}(2100 \mathrm{~m})$ Tolal Number $1.2 \times 10^{6} / \mathrm{m}^{3}(4400 \mathrm{~m})$

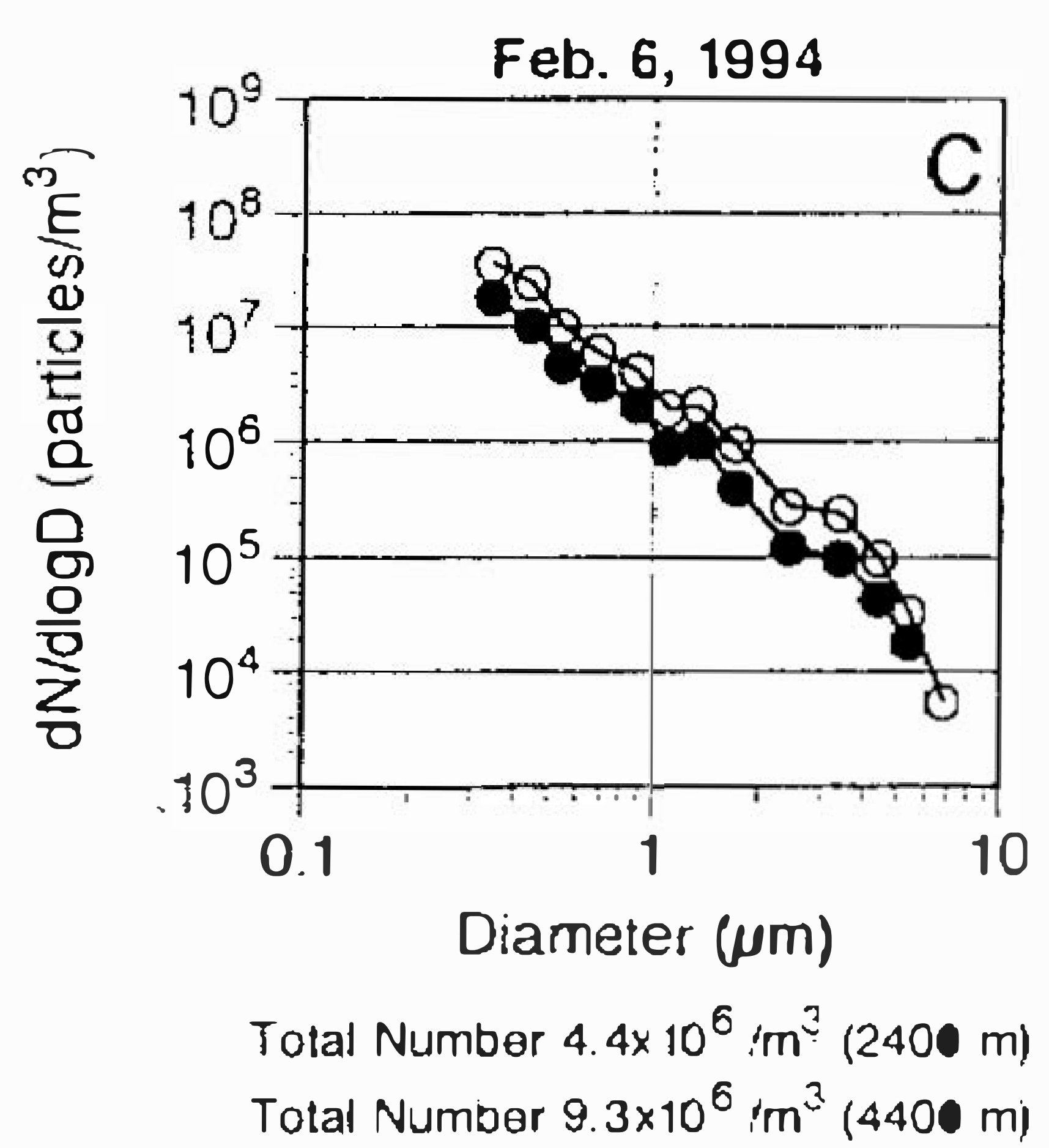

Fig. 9. Example of the possible Kosa effect detected in the winter season over Japan. The Peak of number density is found at about $1 \mu \mathrm{m}$, and sometimes the aerosol load at the $4.4 \mathrm{~km}$ level is larger than that at $2.3 \mathrm{~km}$. This suggests that Kosa particles affect the aerosol load in not only spring but also in other seasons.

\section{SUMMARY AND CONCLUSION}

The number-, mass-, and volume-size distribution patterns measured in the free troposphere with an optical particle counter over Japan are described.

The measurements frequently showed the enhancement of coarse size particles at 2.3 and $4.4 \mathrm{~km}$ in the spring. Additionally, a higher total number and volume concentration were observed at $4.4 \mathrm{~km}$ than at $2.3 \mathrm{~km}$. The appearance of a highly concentrated aerosol layer in the free troposphere is expected to be due to the long range transport of soil particles from the Asian continent from the trajectory analysis of an air mass. Lidar measurements also showed the enhancement of particulate matter in the free troposphere even though a typical dust storm episode was not reported in the boundary layer atmosphere.

The volume-size distribution patterns estimated from the number-size distributions show a peak in the supermicron size range, and the same type of volume-size distribution has been frequently observed in the surface atmosphere during dust storm episodes. The appearance of such a type size distribution was more frequent at $4.4 \mathrm{~km}$ than at $2.3 \mathrm{~km}$, suggesting the effect of a long range transport of Kosa particles in the free troposphere. This free tropospheric disturbance found in the present measurements possibly corresponds to the weak Kosa which was the enhancement of the aerosol load in the spring troposphere and, which was suggested 
as an important component of atmospheric particles on the basis of lidar measurements (Iwasaka et, al., 1988).

The mass-size distribution pattern simultaneously observed correspond well with those enhancements of coarse size particles in the free troposphere even though no enhancement of aerosol load was detected in the surface atmosphere. These features, as is the case with measurements on number-size distribution and volume-size distribution, can be explained by the effect of the prevailing westerly wind over Japan out of the summer season. Owing to the limitations of flight time, the present observation of mass-size distribution is based on the 2-hours continuous collection of particulate matter during the level flight. The collection time should be expanded in future research since the density of particles with a few $\mu \mathrm{m}$ is extremely low rendering the data quality low in term of the mass-size distribution in the range of a few $\mu \mathrm{m}$.

The present observations suggest the enhancement of particle concentration in the free troposphere in fall and winter in addition to spring. If these events are due to the long range transport of particles from the Asian continent, the effect of the continet is more severe than the level previously expected. This is because, mainly on the basis of ground based sampling of particulate matter, spring has been thought of as the time when Asian continent particles are transported by strong westerly winds.

The relationship between the nature of the source region of soil particles and long range transport processes should be studied in more detail, and a detailed comparison of free tropospheric aerosols and the particles in the boundary layer atmosphere should also be made so as to provide an understanding of the effect of Asian dust particles on the global budget of particulate matter.

As the observations of mass- and number-size distribution in the free atmosphere are v'ery limited, more observations are needed to confirm the effect of Kosa event on the budget of soil particles. Measurements on the chemical composition of those particles are also desired so that the behavior of Asian dust particles in the free atmosphere may be understood.

Acknowledgements The aircraft measurements used here were supported by the Ministry of Education, Science and Culture, Japan under the program, Grant-in-Aid for Creative Fundamental Research; Studies of Global Environmental Change with special reference to Asia and the Pacific Region.

\section{REFERENCE}

Asano, S., and M. Shiobara, 1989: Aircraft measurements of the radiative effects of tropospheric aerosols: Observational results of the radiation budget. J. Weteor. Soc. Japan, 67, 847-861.

Arao, K., and Y. Ishizaka, 1986: Volume and mass of yellow sand dust in the air over Japan as estimated from atmospheric turbidity. J. Meteor. Soc. Japan, 64, 79-94.

Betzer, P. R., K. L. Carder, D. K. Costello, R. W. Young, R. A. Duce, J. T. Merrill, N. W. Tindale, M. Uematsu, and R. A. Fely, 1988: Long range transport of giant mineral aerosol particles. Nature, 336, 568-571. 
Duce, R. A., R. Arimoto, B. J. Ray, C. K. Unni, and P. J. Harder, 1983: Atmospheric trace elements at Enewetak atoll: 1, concentrations, sources, and temporal variability. J. Geophys. Res., 88, 5321-5342.

Gao, Y., R. Arimoto, M. Y. Zhou, J. T. Merrill, and R. A. Duce, 1992: Relationships between the dust concentrations over eastern Asia and the remote North Pacific. J. Geophys. Res., 97, 9867-9872.

Gillette, D. A., and J. Hansen, 1989: Spacial and temporal variability of dust production caused by wind erosion in the United States. J. Geophys. Res., 94, 2197-2206.

Hayasaka, T., T. Nakajima, and M. Tanaka, 1990: The coarse particle aerosols in the free troposphere around Japan. J. Geophys. Res., 95, 14039-14047.

Hayasaka, T., T. Nakajima, S. Ohta, and M. Tanaka, 1992: Optical and chemical properties of urban aerosols in Sendai and Sapporo Japan. Atmos. Environ., 26A, 2055-2062.

Hoppel, W. A., J. W. Fitzgerald, G. M. Frick, R. E. Larson, and B. J. Wattle, 1987: Preliminary investigation of the role that DMS and cloud cycle play in the formation of the aerosol size distribution, NRL Report 9032, Naval Research Laboratory, Washington DC., 1-81.

Iwasaka, Y., 1986: Measurement of depolarization ratio of stratospheric particles by lidar a case study on disturbed stratospheric aerosol layer by the volcanic eruption of $\mathrm{Mt}$. El Chichon. J. Geomag. Geoelectr., 38, 729-740.

Iwasaka, Y., M. Yamato, R. Imasu, and A. Ono, 1988: Transport of Asian dust (KOSA) particles; importance of weak KOSA events on the geochemical cycle of soil particles. Tellus, 40B, 494-503.

Kawahara, M., 1992: Climate of Japan, Spring (March-May, 1992), Kishou (in Japanese), No. 424, 38-40.

Kawahara, M., 1993: Climate of Japan, Spring (March-May, 1993), Kishou (in Japanese), No. 436, 36-38.

Kreidenweis, S., J. E. Penner, F. Yin, and J. H. Seinfeld, 1991: The effect of dimethylsulfide upon marine aerosol concentrations. Atmos. Environ., 25A, 2501-2511.

Kristament, I. S., J. B. Liley, and M. J. Harvey, 1993: Aerosol variability in the vertical in the southwest Pacific. J. Geophys. Res., 98, 7129-7139.

Lechner, I. S., G. W. Fisher, H. R. Larsen, M. J. Harvey, and R. A. Knobben, 1989: Aerosol size distribution in the southwest Pacific. J. Geophy's. Res., 94, 14893-14903.

Meinert, D. L., and J. W. Winchester, 1977: Chemical relationships in the north Atlantic marine aerosol. J. Geophy's. Res., 82, 1778-1782.

Okada, K., Y. Ishizaka, and T. Takeda, 1986: Features and behavior of submicrometer aerosol particles in the urban atmosphere of Nagoya. J. Meteor. Soc. Japan, 64, 755-763.

Okada, K., H. Naruse, T. Tanaka, O. Nemoto, Y. Iwasaka, P.-M. Wu, A. Ono, R. A. Duce, M. Uematsu, J. T. Merrill, and K. Arao, 1990: X-ray spectrometry of individual Asian duststorm particles over the Japanese islands and the north Pacific ocean. Atmos. Environ., 24A, 1369-1378.

Patterson, E. M., D. A. Gillette, and G. W. Grams, 1976: The relation between visibility and the size-number distribution of airborne soil particles. J. Appl. Meteor., 15, 470-478. 
Patterson, E. M., C. S. Kiang, A. C. Delany, A. F. Wartburg, A. C. D. Leslie, and B. J. Hurbert, 1980: Global measurements of aerosols in remote continental and marine regions: concentrations, size distribution and optical properties. J. Geophys. Res., 85, $7361-7376$.

Prospero, J. M., R. J. Charlson, V. Mohnen, R. Jaenicke, A. C. Delany, J. Moyers, W. Zoller, and K. Rahn, 1983: The atmospheric aerosol system: An overview. Rev. Geophys. Space Phys., 21, 1607-1629.

Takano, S., 1994: Climate of Japan, Spring (March-May, 1994), Kishou (in Japanese), No. 448, 36-38.

Takeuchi, S., and J. Kondoh, 1993: Measurements of the boundary layer in Japan. The atmosphere near the ground Tokyo University Press, 57-70 (in Japanese).

Tanaka, M., T. Nakajima, M. Shiobara, M. Yamano, and K. Arao, 1989: Aerosol optical characteristics in the yellow sand events observed in May, 1982 at Nagasaki - Part 1. Observations. J. Meteorl. Soc. Japan, 67, 267-278.

Tanaka, M., T. Hayasaka, and T. Nakajima, 1990: Airborne measurements of optical properties of tropospheric aerosols over an urban area. J. Meteor. Soc. Japan, 68, 335-345.

Twomey, S., 1976: Aerosol size distributions by multifilter measurements. J. Atmos. Sci., 33, 1073-1079. 